REVISTA DE DERECHO UNED, NÚM. 12, 2013

\title{
LA COMPETENCIA DE LOS CÓNSULES EN LOS ACTOS DE JURISDICCIÓN VOLUNTARIA MERCANTILES. HISTORIA, TRADICIÓN, ACTUALIDAD Y CONVENIENTE REFORMA
}

\author{
COMPETENCE OF CONSULS IN CASES OF VOLUNTARY \\ JURISDICTION IN COMERCIAL LAW. HISTORY. TRADITION. \\ PRESENT STATE AND CONVENIENT REFORM
}

\author{
Juan Manuel Alonso Furelos \\ Titular de Derecho Procesal
}

Resumen: Cónsules y Consulado son una Institución histórica. Nace en Roma, en la República, donde se consolida y extingue y es de Derecho Público Romano. En la Baja Edad Media surge como derecho privado, en las Repúblicas Italianas de donde llega a España, para defender los intereses jurídicos de los comerciantes que van a «disponer» de un derecho «especial» privado que éstos aplican dentro de una «jurisdicción especial privilegiada mercantil» que tutela jurídicamente «sus» asuntos sean jurisdicción contenciosa o voluntaria. En el S. XIX, esta figura deviene pública para defender los intereses comerciales del Estado, en el país extranjero donde se hallan sus Consulados.

En 1868 en España desaparece la jurisdicción mercantil cuyo cometido es asumido por la jurisdicción ordinaria en su orden civil. Desde entonces Cónsules y Consulados son una figura de derecho público, dependientes del Ministerio de Asuntos Exteriores para la defensa de los intereses comerciales españoles, en el país en que se hallan. La LEC 1881 les confía por tradición funciones mercantiles en la jurisdicción voluntaria que hoy estando aún «vigentes» son simples «recuerdos obsoletos» de otras épocas ya superadas. 
La cercana reforma de la jurisdicción voluntaria puede ser un pretexto para confiar a Cónsules y Personal Diplomático de nuestras Embajadas la competencia en "casi todos sus asuntos» cuando se solicite su intervención por españoles que están en esos países.

Abstract: Consuls and Consulate are a historic institution of Roman Public law, with origins in Rome during the Republic, where it was consolidated and then extinguished. In the Low Middle Ages it arose as private right, and arrived in Spain from the Italian Republics, to defend the juridical interests of the merchants who would exercise a «special» private law which they would apply within a «special privileged mercantile jurisdiction «which would govern juridically "their» matters, whether of contentious or voluntary jurisdiction. In the 19th century, this institution became public in order to defend the commercial interests of the State, in the foreign country where its Consulates were situated.

In 1868 The Mercantile Jurisdiction disappeared its jurisdiction was subsumed into that of the Ordinary Civil Jurisdiction of the Court. Since then, Consuls and Consulates are an institution of public law and are servants of the Ministry of Foreign Affairs to defend of the commercial interests of Spaniards, in the country where they are located. The LEC 1881 entrusted them the voluntary jurisdiction in mercantile matters, that today are still «in force» but exist in fact simply as «obsolete memories» of a bygone era.

The approaching reform of this voluntary jurisdiction may be a pretext to entrust to our consuls and diplomatic personnel of our embassies, competence "in almost all matters» when they are requested by Spaniards who are located in those countries.

Palabras clave: Cónsules. Derecho Internacional Público y Privado. Derecho Marítimo Mercantil. Derecho Procesal. Historia. Jurisdicción Mercantil. Jurisdicción Voluntaria.

Keywords: Consuls. Public and Private International Law. Mercantile Maritime Law. Procedural Law. History. Mercantile Jurisdiction. Voluntary Jurisdiction.

Recepción original: 30/05/2013

Aceptación original: 05/06/2013

Sumario. I. Introducción. II. Historia y tradición. III. Régimen vigente: 1) Sucesiones normativas; 2) Requisitos; 3) Ámbito; 4) Clasificación; 5) Naturaleza jurídica y carácter de los Cónsules; 6) Procedimiento y recursos. IV. Líneas de la futura reforma a modo de conclusiones. V. Bibliografía. 


\section{INTRODUCCIÓN}

El estudio de una institución, de las normas que la regulan y en las que se contiene, de una u otra forma es el fruto o consecuencia de su interpretación.

Cuando la persona que la lleva a cabo es el propio legislador se denomina auténtica y nos manifiesta en la Exposición de Motivos las razones del nacimiento de la Ley. Véase ésta en la LEC 1881 para la jurisdicción voluntaria en asuntos de comercio. Cuando la realizan los Jueces y Tribunales para concretar el contenido de las normas, al aplicarlas al caso concreto, se denomina interpretación judicial; si buscamos la referida a los Cónsules de los artículos 2109 y ss. LEC, referida el momento presente, es inexistente.

Finalmente cuando es llevada a cabo por los estudiosos del derecho es doctrinal, como es mi caso, aunque solo sea un simple iniciado en el derecho con mayor o menor fortuna y sin otra pretensión o aspiración. Esto me supone que para estudiar una figura jurídica no conozco otro camino que interpretarla para desentrañar su contenido.

Cuando afirmo que «sin otra pretensión», sinceramente, quiero decir y dejar claro que ni aspiro ni me preocupa -por el momentosentar doctrina y como esa no es mi aspiración tampoco aspiro a lo que se denomina en medios universitarios «sentar cátedra» ni tampoco a encontrar la verdad más o menos absoluta o inmutable de las consecuencias o conclusiones jurídicas alcanzadas denominadas por otros «tesis» en que desemboque este trabajo lo que implica que las afirmaciones mantenidas no tienen en «ningún caso» el alcance de la cosa juzgada de las resoluciones judiciales que se pronuncian sobre el fondo. Desde este momento, este aspecto, para el lector queda meridianamente claro.

Cuando el Código Civil, en su Título Preliminar -por tanto de aplicación a todas las disciplinas jurídicas-, en su artículo 3-1 establece los criterios de interpretación para entender el sentido y contenido de las normas lo hace partiendo de las premisas de todos conocidas. Cosa distinta es que tenga, o no -o mejor dicho, que deba, o no-, seguir el orden de enumeración de estos medios interpretativos que sigue el Código Civil.

En efecto, el CC al referirse a los criterios, medios o formas de interpretación sigue el siguiente orden: primero el etimológico y gramatical de las palabras dentro de su contexto o interpretación literal; 
segundo el histórico atendiendo a sus antecedentes legislativos o interpretación histórica; tercero el momento presente o actual en que han de ser aplicadas atendiendo a la realidad social que demanda el cuerpo social o sociedad (dígase además, incluido en éste, la realidad política y económica y la forma de Estado en un modelo constitucional) es decir su interpretación en el presente en que son aplicadas las normas vigentes; cuarto la interpretación conjunta o sistemática dentro del sistema global que integra el ordenamiento jurídico por tanto no sólo dentro del cuerpo legal en que se contienen todas, las más o sólo algunas si no en atención a los distintos cuerpos que las contienen sin olvidar su diferente jerarquía, pues las normas jurídicas no son compartimentos estancos sino compartimentos que se relacionan entre sí como los vasos comunicantes o interpretación sistemática; y el quinto finalmente atendiendo al espíritu y finalidad que persiguen las propias normas o interpretación finalista o teleológica a la que se puede referir la exposición de motivos de las normas como la jurisprudencia de los Tribunales, especialmente la del Supremo o Constitucional según sea el objeto aplicado.

Por razones de sistemática, como señalo en el sumario del trabajo, comenzaré con el estudio histórico de esta institución lo que me permitirá a través de su interpretación histórica desentrañar la razón de su origen, el motivo de su sostenimiento durante siglos es decir la razón de ser de su tradición jurídica. A ello dedicamos el epígrafe II.

Seguiré con el estudio del momento vigente que arranca con el Decreto de Unificación de Fueros de 1868, la LOPJ de 1870 y la LEC de 1881. Consagran las dos primeras normas la desaparición de la jurisdicción mercantil y de la competencia de los Cónsules y la atribución de los asuntos mercantiles a la jurisdicción ordinaria. La tercera consagra la reaparición de la competencia de los Cónsules, dentro de la jurisdicción ordinaria, para ciertos supuestos de jurisdicción voluntaria de negocios de comercio en concurrencia con ciertos requisitos.

Exige una interpretación referida al momento presente atendiendo y comprendiendo el sentido de las normas en lo literal y gramatical; sistemática, en especial, de la Ley de Enjuiciamiento Civil de 1881 concordada con la Ley Orgánica del Poder Judicial de 1870 y la posterior de 1985 (6/1985 de 1 de julio) que nada añade a la cuestión; de las leyes materiales como el Código de Comercio de 1829 modificado por el de 1885 (no se olvide que la LEC es de 1881 y todavía no existía este último) y la legislación mercantil especial. Sin olvidar la interpretación sociológica, que la sociedad de la 
época reclamaba por razones de política económica y mercantil y la teleológica o fin perseguido por las normas materiales y del procedimiento reguladoras de la situación en 1881 que en nada se asemejan al momento presente. Dedicaré los epígrafes II y III.

Terminaré manifestando -cómo no- mi particular desazón, una cierta insatisfacción o zozobra más que congoja, o al menos la inquietud de que los resultados obtenidos o alcanzados puedan parecer insuficientes.

Y ello será así porque el fruto alcanzado con el uso de los medios de interpretación empleados es decir el histórico, literal o gramatical, sistemático, social y finalista nos conducen a la conclusión de que los tiempos irremediablemente han cambiado y que la jurisdicción voluntaria en asuntos mercantiles conferida a los Cónsules precisa de una futura reforma que la clarifique, complemente y la adecue al momento presente.

Y no sólo señalar esto que resulta muy cómodo con solo afirmarlo sino intentar destacar -aun a riesgo de equivocarme, lo cual a todas luces me parece secundario- cuales deberían ser los cauces de esa reforma. Como digo, el hecho de que esta propuesta de reforma esté equivocada o no sea la adecuada a los ojos de otros juristas es inocuo ya que al menos servirá para que se inicie el preciso y adecuado debate en una institución que parece destinada a una inmediata reforma sin perjuicio y repito nuevamente que para mí, de ser así, ya serían secundarios los derroteros que la harían posible.

La cuestión de estos derroteros no es baladí, pues están en juego los intereses de varias disciplinas jurídicas a las que afectará.

Al derecho procesal, si se determina en el caso de los Cónsules (y personal de las Legaciones Españolas) que estamos ante una competencia judicial funcional para la primera fase del procedimiento de estos expedientes (transcurre desde la solicitud hasta su resolución por auto) y que lo es por delegación del Estado; si queremos que sea extraordinaria para ciertos supuestos u ordinaria para todos; definitiva o sólo a prevención y sólo en este último caso precisaría de un reconocimiento por los Jueces de Primera Instancia o Juzgados de lo Mercantil (esto ni siquiera queda claro en la vigente ley pudiendo defenderse o combatirse una u otra línea, en el futuro, de lege ferenda).

Afecta al derecho administrativo si mantenemos que estamos ante una competencia meramente administrativa y no judicial de unos funcionarios del Estado que son los Cónsules o personal diplomático de Legaciones Españolas y que forman parte de la Ad- 
ministración general del Estado adscritos al Ministerio de Asuntos Exteriores.

En uno u otro caso, sea el Cónsul órgano jurisdiccional o administrativo, el régimen de impugnación de estas decisiones ha de ser diferente, es decir seguirse el régimen "procesal» referido a los actos de jurisdicción voluntaria admitiendo el recurso de reposición contra sus providencias o la mera protesta oral en la comparecencia y en su caso el de apelación contra su auto si se mantiene la vigencia de este recurso en la jurisdicción voluntaria; o por el contrario se sigue el régimen administrativo común de impugnación de sus actos mediante el recurso de alzada (sin perjuicio de especialidades en la impugnación administrativa que el legislador en el futuro crea convenientes).

Afecta al Derecho Constitucional pues la función del Cónsul si se considera órgano jurisdiccional puede encuadrarse en el artículo $117 \mathrm{CE}$ dentro del Título destinado al Poder Judicial y si es órgano administrativo dentro del Título IV del Gobierno y de la Administración en ambos casos se trata de una competencia exclusiva del Estado del Título VIII la regulación de las funciones de los Cónsules o personal de Legaciones diplomáticas que nunca puede corresponder a las CCAA como también es competencia exclusiva del Estado la regulación de la legislación mercantil y de la «procesal» de jurisdicción voluntaria que deben aplicar los Cónsules al caso concreto.

Afecta a las garantías constitucionales si se considera al Cónsul órgano jurisdiccional y a la jurisdicción voluntaria una manifestación del derecho a la tutela judicial efectiva que tienen los justiciables por el mero hecho de serlo -derecho de acceso a ésta que es una manifestación de su derecho a la jurisdicción- al que se refiere el artículo 24 de la CE y que deben prestar los Jueces y Tribunales en cuanto obligados a su desempeño por ser a quienes se encomienda la jurisdicción con las garantías a que se refiere el artículo $117 \mathrm{CE}$.

Y en esta perspectiva afecta al propio sistema político, al modelo de Estado que tenemos y que necesitamos o precisamos reformar, por tanto al mismo derecho político, al derecho constitucional y a la propia Filosofía del Derecho siempre entendida desde la concepción positivista que sostengo vinculada a un modelo de Estado que forma parte de la teoría general de éste (Kelsen).

Afecta al derecho mercantil, pues los actos de comercio a que se refiere la jurisdicción voluntaria tienen carácter, como no podía ser menos, exclusivamente mercantil. Y deberán ser los mercantilistas 
los que se pronuncien sobre cuales de esos actos deben mantenerse dentro de la jurisdicción voluntaria y cuales deben incorporarse a ella de forma novedosa y en su caso cuales ser de la competencia de los Cónsules y cuales corresponder a los Jueces de Primera Instancia o a los Juzgados de lo Mercantil.

Implica al derecho internacional público ya que los Cónsules son funcionarios públicos dependientes del Ministerio de Asuntos Exteriores y deberán pronunciarse sus estudiosos sobre la adecuación -o no- de que esta competencia de jurisdicción voluntaria solicitada por españoles en los países donde existe Consulado siga siendo desempeñada por los Cónsules y si sólo en el ámbito mercantil o también en el civil y con que extensión; como igualmente si es conveniente o procedente que los actos de jurisdicción voluntaria civiles y mercantiles solicitados por los españoles en esos países puedan ser desempeñados también por el personal diplomático de las Embajadas Españolas en cuanto dependen del Ministerio de Asuntos Exteriores.

También afecta al derecho internacional privado en tanto en cuanto los actos de jurisdicción voluntaria de los Cónsules son actos de carácter público referidos a materias de derecho privado que se llevan a cabo en el extranjero y por esa razón si deben tener un carácter diferenciado con los llevados a cabo por los jueces o las autoridades de los países extranjeros en cuestión (cuando los interesados no puedan acudir al Consulado o Embajada por las razones que fueran o porque no existen éstos en esos países) es decir todo el tema del reconocimiento y homologación por las autoridades españolas de las decisiones de jurisdicción voluntaria de las autoridades extranjeras cuando deban producir o desplegar efectos en territorio nacional. Con más claridad si las decisiones de los Cónsules no precisan de homologación alguna por los Jueces y Tribunales españoles del lugar donde deben desplegar efectos equiparándolos a las de éstos considerándoles propiamente autoridad judicial, o si sus decisiones deben ser homologados pero con menor intensidad que las dictadas por autoridades extranjeras dado que los Cónsules son autoridades españolas con la consideración de funcionarios.

Incluso afectaría al derecho civil, si permitimos -como propugno- que todos los actos de jurisdicción voluntaria de carácter exclusivamente civil - a salvo de contadas excepciones- solicitados por españoles en esos países pudieran ser encomendados tanto a los Cónsules como al personal diplomático de las Embajadas. 
Finalmente, desde el punto de vista histórico importa tanto al derecho romano -sin olvidar que los Cónsules en el derecho romano asumían funciones públicas y por ello tenían una significación muy diferente que la alcanzada después por los Cónsules y los Consulados desde la Baja Edad Media por el influjo del comercio hasta el S. XIX. Y a los historiadores del derecho, desde la Baja Edad Media como decimos comenzando con su estudio en la República de Venecia y de otras Repúblicas Italianas donde aparece y se constituye su significación mercantil.

Recalco al derecho romano puede interesar el inicio y la significación pública de los Cónsules en la República y el porqué de su desaparición con el Imperio Romano.

A la Historia del Derecho y a la Historia del Derecho Mercantil en su significación privada para conocer el porqué del triunfo institucional alcanzado desde la Baja Edad Media de los Cónsules, Consulados y la Jurisdicción Consular mercantil hasta el siglo XIX en que pasó a convertirse el Cónsul y el Consulado, en los distintos Estados, en una institución pública al servicio de la Administración Exterior del Estado como bien conocen los estudiosos de la historia del derecho internacional público.

\section{HISTORIA Y TRADICIÓN}

1. En el derecho romano la figura de los Cónsules tiene especial significación durante la República, teniendo una alta distinción y condición, siendo su número muy reducido ya que las fuentes hablan de dos y con una duración en el cargo temporal reducida a un año y con suprema autoridad en el ejercicio de sus funciones. Al principio ostentaban funciones militares importantes por delegación del Senado y sobre todo funciones políticas para convocar al Senado o convocatorias consultivas populares. También función jurisdiccional en el ámbito penal, al más algo nivel, y en última instancia.

Sus funciones no eran sólo jurisdiccionales en lo penal sino otras de carácter político y las ostentan como Suprema Autoridad. En nada eran equiparables sus funciones a las del Pretor en el ámbito civil o privado del «ius commune» al que pertenecía el derecho mercantil que entonces carecía de autonomía propia.

El Pretor y después el Magistrado desempeña funciones jurisdiccionales ordinarias como hoy nuestros Jueces y Tribunales. Los Cónsules tienen carácter extraordinario y su función jurisdiccional 
es excepcional, únicamente en lo penal en última instancia; además los Cónsules asumían funciones políticas importantes para convocar al Senado y a la Ciudadanía como las que les pudiera delegar el Senado una vez convocado.

Los Cónsules y sus funciones desaparecen con el surgimiento del Triunvirato y el Imperio al ser asumidas por el Triunvirato o el Emperador desde fines del S. I A.C. Sus funciones nacen, se desarrollan y mueren por tanto durante la República Romana.

Concluyendo en el derecho romano las funciones públicas de los Cónsules no son equiparables a las privadas que asumen en el derecho bajo medieval; ni las funciones jurisdiccionales extraordinarias de los primeros son equiparables a las jurisdiccionales ordinarias de los segundos en las contiendas entre comerciantes desde fines del S. XIII; de la misma forma los actuales Cónsules en cuanto funcionarios públicos del Ministerio de Asuntos Exteriores y sus funciones no se parecen a las de los anteriores.

Un estudio completo y desarrollado de las funciones de los Cónsules en el derecho romano es ajeno al objeto de este trabajo y por ello serán los romanistas los encargados, en su caso, del estudio y sistematización de sus funciones durante la República y de abordar su razón de ser política y jurídica y de la pérdida de sus funciones y de que sean asumidas por el Triunvirato y después por el Emperador desde fines del S. I A .C.

Desde otra perspectiva, y como estamos abordando la jurisdicción voluntaria mercantil, debe señalarse que durante la República Romana la noción de jurisdicción voluntaria es desconocida al Derecho Romano. Es desde el S. III D.C en un texto atribuido a Marciano, cuando la doctrina moderna romanista empieza a hablar de la noción de jurisdicción voluntaria en el Derecho Romano, aunque estamos ante un texto discutido y discutible en cuanto a su autenticidad y el alcance de la institución. Los estudiosos del derecho romano, en la actualidad, al abordar la jurisdicción voluntaria en el Derecho Romano de esta época S. III D.C señalan que el ámbito de la jurisdicción voluntaria no estaba sólo referido al «ius commune» de la Metrópoli o península Itálica (muy reducido y no sólo atribuido al Magistrado) sino que se extendía al ámbito de las provincias del Imperio «ius provinciae» y con un contenido diferenciado. Y la competencia para la jurisdicción voluntaria estaba atribuida no sólo al Magistrado con carácter general dentro del ámbito del «ius commune» de la Metrópoli sino también a otros funcionarios provinciales llamados «Pro Cónsules», que nada tenían que ver con los anteriores 
Cónsules, que ejercían funciones públicas con poder delegado en las provincias como si se tratara de «Magistraturas Especiales» por su especial significado y que por tanto serían el antecedente próximo de las «Jurisdicciones especiales privilegiadas».

Queda claro que la arrogación, manumisión, agnación, adopción e instituciones semejantes del derecho de familia y otras que afectaban, igualmente, al derecho de sucesión no podían ser encomendadas solo a personas que ejercían la jurisdicción civil privada -Magistrado en la Metrópoli- sino a funcionarios especiales también denominados «Pro Cónsules» a los que se encomendaban estos asuntos muy importantes para esta época. Ampliamente véase a Fernández Bujan, A.

Destacar que en el derecho Romano no existe la distinción propia que aparece en la Edad Media entre el «ius commune o civil» y el derecho especial que se desgaja de aquél para los actos de comercio de los comerciantes o mercantiles o «ius mercatorum». En el derecho romano el comercio y su derecho forma parte del «ius commune» y es encomendado al Magistrado.

Ese ius mercatorum especial desconocido en el derecho romano y que nace en la Baja Edad Media justificará el nacimiento de una jurisdicción especial mercantil encomendada a los Cónsules donde haya Consulado y donde no a comerciantes matriculados en esa plaza elegidos por sus compañeros para ese cometido que es la actuación al caso concreto de las consecuencias jurídicas previstas en ese derecho especial o ius mercatorum. Nace así una jurisdicción contenciosa mercantil, tanto para los asuntos contenciosos donde se pide una condena frente a alguien como para los asuntos de jurisdicción voluntaria o «intervolentes» en que se piden efectos no frente a alguien sino para sí, para los que los solicitan o piden.

2. La Baja Edad Media, como estamos señalando en los dos últimos párrafos del anterior numeral, supuso en el Viejo Continente y especialmente en el área de influencia Mediterránea un auge, antes no conocido, en el comercio y en la economía en comparación con la Alta Edad Media que la precede. Nace o surge para la protección de los intereses de los comerciantes, como acabamos de señalar, un derecho privado especial o «ius mercatorum» y una jurisdicción «inicialmente privada, especial y privilegiada» denominada mercantil para la resolución de sus contiendas o la consecución de efectos jurídicos que el ordenamiento jurídico permite otorgar intervolentes (estamos ante dos medios de tutela jurídica, bajo el prisma de la heterocomposición, que forman la jurisdicción contenciosa y voluntaria). 
Repito, esta jurisdicción mercantil, privada, especial y privilegiada de los Cónsules y comerciantes extiende para sí la competencia para resolver no sólo de los asuntos contenciosos sino de los no contenciosos -en los que todavía no existe contienda y quizá nunca llegue a existir contienda alguna y en los que existe una petición de tutela jurídica concreta de jurisdicción voluntaria mercantil (también denominada en "asuntos comercio» o en "negocios de comercio» según LEC) por los interesados que disponen de legitimación material propia y directa por haber participado directamente en el negocio, relación o situación jurídica material subyacente que los legitima para ello y para pedirla para sí es decir, sólo para los que la piden $\mathrm{o}$ «intervolentes»-.

Quienes imparten esta jurisdicción mercantil, Cónsules y comerciantes, son legos y no tienen carácter permanente al ser elegidos entre los comerciantes matriculados en esa plaza. Sin perjuicio de que Cónsules los hay donde existen Consulados y parece que deben tener unos conocimientos jurídicos más técnicos que los comerciantes cuando la imparten; aunque la experiencia de ser comerciantes facilite su especialización jurídica.

Adelantando ideas la jurisdicción voluntaria es un medio de tutela jurídica específica, diferente de la jurisdicción contenciosa o proceso, ya que en ella no existe ni puede existir contienda, contradicción, partes, ni pretensión, ni se busca la condena de nadie. Es provisional pues no produce los efectos de la cosa juzgada material ni en ningún caso pretende esta aspiración por la propia naturaleza de esta tutela. La producción de la cosa juzgada formal queda desdibujada por el libre acceso al proceso de terceros interesados a los que perjudique la resolución de jurisdicción voluntaria.

Pero es un medio de tutela jurisdiccional en tanto en cuanto es una manifestación de la heterocomposición pública que corresponde al Estado y que a través de él es llevada a cabo -mediante su delegación- por personas que aunque ostenten carácter o condición privada desempeñan una función pública por esa delegación implícita del propio Estado. Junto a la heterocomposición pública existen otras formas de tutela jurídica como son la heterocomposición privada de los árbitros; la autocomposición por los propios legitimados sea antes del proceso o después de iniciado por las partes corresponda la iniciativa a los propios legitimados o a terceros en cuyo caso se llama mediación; la autotutela o autodefensa privada con manifestaciones en el derecho privado y en el derecho penal en las causas de justificación o la autotutela pública llevada a cabo por la Administra- 
ción dentro de sus privilegios como la vía administrativa, la reclamación previa administrativa, la ejecución de sus propias resoluciones administrativas y la ejecución de las sentencias judiciales en sus «justos términos» sea o no condenada la Administración. (A salvo de la ejecución forzosa por la propia jurisdicción -de las sentencias de condena- a la Administración).

Nace así en la Baja Edad Media el derecho mercantil, del comercio o comercial, el «ius mercatorum» y con una jurisdicción especial para aplicarlo en los asuntos mercantiles de jurisdicción contenciosa y voluntaria. Un derecho pensado especialmente -y por ello especialde los comerciantes y de los particulares actos que integran el tráfico jurídico mercantil de estos comerciantes y con significación especial según nos encontremos ante el comercio terrestre o marítimo y cuyas manifestaciones se destacan en el Libro del Consulado del Mar y en las Ordenanzas de Bilbao.

Los Consulados se establecen en las plazas de mayor actividad comercial de la península o metrópoli como de las colonias incluso en países extranjeros (en este caso para la protección de intereses españoles y de comerciantes españoles que allí se encuentran y que es el origen del significado actual); los había en ciudades del interior -en que domina el comercio terrestre-, así Burgos, en la Corona de Castilla ya que el comercio de la lana tuvo gran importancia desde el S. XV y en ciudades marítimas portuarias donde el comercio marítimo es importante, como Bilbao y Sevilla en la Corona de Castilla o Barcelona y Valencia en la de Aragón aunque el Consulado conocía de asuntos mercantiles de comercio terrestre y marítimo.

Esta situación que comienza con la Baja Edad Media en Europa por el auge del comercio se extiende a España y cobra singular importancia desde el S. XIV y se mantiene casi sin cambios hasta el inicio del S. XIX.

3. El Siglo XIX en el mundo del derecho es un siglo de profundos cambios. Se inicia con el influjo de los principios y espíritu de la Ilustración y el Enciclopedismo; los de la Revolución Americana y Francesa; la incidencia de éstos en el Constitucionalismo Americano y Francés y en especial -en nuestro país- en la Constitución de 1812 y las posteriores Constituciones Nacionales de 1837 y 1845; influyen sobre el mandato directo constitucional impuesto en éstas de la exigencia de la codificación legislativa; en la forma de entender e interpretar el derecho bajo los postulados más o menos liberales de la Escuela de la Exégesis lo que supone el fin definitivo de la glosa y el comentario simple en los textos legislativos y en las obras doctri- 
nales; pero sobre todo suponen el nacimiento y sostenimiento de un Estado Moderno bajo unos moldes netamente liberales basados en el libre cambio que, sin embargo, derivarán por las propias necesidades del Estado en el notable crecimiento de su dimensión es decir en el crecimiento desorbitado de sus atribuciones comparadas con tiempos pasados y así poco a poco es concebido el Estado por la Sociedad bajo los moldes del Derecho Administrativo que suponen un Estado más intervencionista.

Esto que es así con carácter general va a influir en gran medida en la figura de los Cónsules como no podía ser de otra forma. En efecto de ser personas privadas por ser comerciantes que ejercen a lo sumo una función pública (por delegación implícita del Estado) cual es la jurisdicción mercantil pasan a ser funcionarios del Estado a partir de la segunda mitad del S. XIX dependientes del Ministerio de Asuntos Exteriores donde sus antiguas funciones privadas- defensa de los intereses de los comerciantes- quedan desdibujadas para pasar a ser funciones públicas tanto para la defensa de los intereses comerciales del Estado español como de los españoles que se encuentran en ese Estado extranjero en su condición de comerciantes.

El Consulado español, en el país extranjero donde existe, no es ya un edificio privado si no de carácter público regulado por el Derecho Internacional Público y el Derecho Administrativo. Repito el papel del nuevo Estado burgués, no resulta baladí para la comprensión del cambio de la institución que nos ocupa.

En efecto, la Constitución de Cádiz de 1812, dentro del Título destinado al Poder Judicial, propugna la unificación de las jurisdicciones en el sentido de que exista una jurisdicción única y ordinaria para todo el territorio nacional; ello implica suprimir, en la medida de lo posible, las anteriores y vigentes jurisdicciones especiales de marcado carácter privilegiado. Tal espíritu se mantendrá en las posteriores Constituciones de 1837 y 1845 inspiradas en aquélla. Igualmente, y de la misma forma la Constitución de 1812 y las posteriores citadas imponen como mandato directo al legislador la codificación por especialidades legislativas y que su ámbito de aplicación sea Nacional.

Esto, más tarde o más temprano, afectaría a la jurisdicción privilegiada mercantil que será suprimida junto a otras jurisdicciones igualmente privilegiadas medio siglo después por el Decreto de Unificación de Fueros de 1868. Esto supone que la jurisdicción mercantil ejercida por los Cónsules -allí donde hubiera Consulados- y donde no los hubiera ejercida por los comerciantes elegidos por sus compañeros entre los matriculados en esa plaza sea asumida por los Jueces 
de Primera Instancia pertenecientes a la Jurisdicción Ordinaria. Esto afectará, no sólo a la primera instancia sino a la segunda instancia del recurso de apelación y al recurso de casación.

Es preciso destacar que la Constitución de Cádiz hizo desaparecer de forma progresiva y no de forma única o instantánea ciertas jurisdicciones especiales. Las primeras en desaparecer y sólo a título de ejemplo fueron la del Tribunal de la Inquisición o Santo Oficio, las de las Órdenes Militares...... en el primer tercio del S. XIX. Y las últimas, en este mismo siglo las previstas por el Decreto de Unificación de Fueros de 1868 debiendo destacarse la desaparición junto a la mercantil a la eclesiástica aunque ésta siguió con algunas excepciones residuales manteniendo su régimen hasta el Concordato vigente con la Santa Sede y el posterior Acuerdo con ésta de 1978 que siendo preconstitucional fue publicado después de su vigencia en el BOE en enero de 1979.

El espíritu liberal de la Revolución Americana y Francesa, en el ámbito comercial y las doctrinas librecambistas, se materializan en la legislación mercantil española concretamente en el primer Código de Comercio de 1829 en lo sustantivo y en la Ley de Enjuiciamiento de Negocios de Comercio de 1830 en el plano procesal.

Se trata de una legislación nueva, fruto de los primeros intentos codificadores (antes la codificación penal de 1822) y que en el ámbito jurisdiccional respetó hasta 1868 esa jurisdicción privilegiada especial mercantil de carácter clasista, popular y de base consuetudinaria, por tanto la ejercida por los Cónsules -donde había Consulados- y por los comerciantes elegidos entre los matriculados en la plaza donde no existen.

Finalmente los postulados de la Escuela de la Exégesis, centrados en el respeto exclusivo al principio de legalidad (hasta el punto de que la Ley en cuanto norma escrita es la principal fuente y base del derecho establecido y lo que no aparece en ella no se debe tener por tal) supondrán un cambio sustancial en el estudio de las disciplinas jurídicas. En nuestro caso tanto de la legislación sustancial o material mercantil establecida fundamentalmente en el Código de Comercio de 1829 y de la formal o procedimental mercantil de la Ley de Enjuiciamiento de Negocios de Comercio de 1830. Los postulados de la Escuela de la Exégesis dan con el traste, como ya señalamos, en el método de investigación jurídico seguido en España antes de la codificación basado sobre todo en la glosa y el comentario simple del texto sin olvidar que ya fuera de España incluso en el ámbito de la legislación las ideas del enciclopedismo ya habían supuesto un 
profundo cambio que en España apenas tuvieron influencia debido a la «censura» de la Inquisición.

Para terminar este epígrafe destacar que el nacimiento del Estado moderno en el S. XIX bajo moldes liberales supondrá nos guste o no el aumento de sus funciones y que su sobre dimensión supone un cambio total en el papel de los Cónsules. De personas privadas que ejercen el comercio, que se ocupan de los Consulados y ejercen la función jurisdiccional contenciosa o «voluntaria» por elección de sus compañeros pasarán a convertirse en funcionarios públicos que representan al Estado Español en el extranjero, en los Consulados Españoles, y por tanto dependientes del Ministerio de Asuntos Exteriores encargados de velar por los intereses del Estado y de los Españoles en ese lugar. Muchas de sus funciones antes privadas pasan a ser públicas al estar encaminadas a la protección de los intereses del Estado Español y no difieren en su naturaleza con las asumidas por las Embajadas Españolas en los países donde se hallan.

Podemos concluir -mediante la interpretación histórica y su teleología- que las normas que atribuyen la competencia para decidir los asuntos de comercio contenciosos y no contenciosos a la jurisdicción mercantil de los Cónsules y comerciantes suponen un «privilegio subjetivo» desde la Baja Edad Media y se deben a razones fundadas en la «especialidad normativa de su derecho sustantivo o material lo que supone un «privilegio objetivo» frente al carácter ordinario del derecho común o civil; a la necesidad de una tutela rápida y urgente en la resolución de sus asuntos por la «especialidad» del tráfico mercantil que lleva consigo la «especialidad normativa procedimental» sea contenciosa (procesos mercantiles) o sea no contenciosa (jurisdicción voluntaria mercantil) para aplicar ese derecho material al caso concreto y que supone un "privilegio objetivo»; especialidad que por estas razones supone además un "privilegio subjetivo» para los comerciantes que reclaman una tutela jurídica de pronta decisión por estos dos medios.

\section{RÉGIMEN VIGENTE}

\section{Sucesiones normativas}

1-1. Decreto de Unificación de Fueros de 1868. Efectos sobre el Código de Comercio de 1829 y la Ley de Enjuiciamiento de Negocios de Comercio de 1830. La Ley Orgánica del Poder Judicial de 1870. 
No abordaremos en este estudio la Ley de Enjuiciamiento Civil de 1855 ya que se refería sólo a los procesos civiles y a los actos de jurisdicción voluntaria civiles. Se decidían por el orden civil de la jurisdicción ordinaria es decir por los Jueces de Primera Instancia, en esta instancia.

En esta fecha los procesos mercantiles y los actos de jurisdicción voluntaria de comercio se regulaban en la Ley de Enjuiciamiento de Negocios de Comercio de 1830 y en lo sustantivo en el Código de Comercio de 1829 y eran decididas por la Jurisdicción Mercantil.

La «Gloriosa» supuso, además del destronamiento de Isabel II en 1868 y de la proclamación de la Primera República Española, llevar a la realidad en ese año, uno de los hitos proclamados y deseados desde la Constitución de Cádiz y las posteriores cual era la supresión y desaparición de las Jurisdicciones especiales e incluir su cometido y funciones dentro de la jurisdicción ordinaria. Ya señalamos antes que la muerte de Fernando VII supuso la supresión de algunas jurisdicciones especiales como ya señalamos, en especial, por su repercusión la de la Santa Inquisición o Santo Oficio y la de las Órdenes Militares pero no afectó a todas.

El Decreto de Unificación de Fueros de 1868, derogó y suprimió algunas de las jurisdicciones especiales que quedaban vigentes entre ellas la mercantil; supuso la supresión jurisdiccional del cometido de los Cónsules y comerciantes en su ámbito y contenido; este cometido pasó a formar parte de la jurisdicción ordinaria en el orden jurisdiccional civil. Los Cónsules y los comerciantes perdían la jurisdicción mercantil que pasa a la jurisdicción ordinaria de los Jueces de Primera Instancia.

En concreto perdían definitivamente Cónsules y comerciantes su cometido contencioso que pasó a formar parte de la ordinaria atribuida a los Jueces de Primera Instancia, para esta instancia; perdían definitivamente los comerciantes la competencia para actos de jurisdicción voluntaria que pasa a los Jueces de Primera Instancia en la misma; perdían momentáneamente los Cónsules la jurisdicción voluntaria que pasó a los de Primera Instancia hasta 1881 pero recuperarán ésta en 1881 sólo para actos de jurisdicción voluntaria que deban practicarse en el extranjero donde exista Consulado Español y en ciertas circunstancias de urgencia y quedan insertos en la jurisdicción ordinaria (ya no pertenecen a la mercantil al haber sido suprimida) aunque no queda claro si insertos como órgano jurisdiccional especial por su regulación en la LEC de 1881 o como órgano administrativo al que se delegan funciones de jurisdicción 
voluntaria dado el régimen diferenciado de los Cónsules con el Juez de Primera Instancia y el silencio de la LOPJ 1870 desde 1881 hacia los Cónsules.

En segunda Instancia para asuntos contenciosos o voluntarios la competencia corresponde desde este Decreto de 1868 a las Audiencias Provinciales; en los contenciosos se admite recurso de casación ante el TS; y en la jurisdicción voluntaria se discute por la doctrina si procede o no el recurso de casación, duda que despejó la reforma de la LEC de 1984 que expresamente lo impide en ésta.

Se asimilan y equiparan los órganos jurisdiccionales de la jurisdicción ordinaria en el orden civil tanto para las contiendas civiles como mercantiles al ser igual su competencia. Igual ocurre para los actos de jurisdicción voluntaria civil y mercantil.

La LOPJ de 1870 no habla en ningún momento de jurisdicción mercantil al haber sido suprimida y ser atribuidas sus competencias a la jurisdicción ordinaria en el orden civil. Se confirma el Decreto de 1868 que la confiere a los Jueces de Primera Instancia en esta primera instancia, a las Audiencias Provinciales para ese orden en la segunda instancia y al Tribunal Supremo en este orden para la casación. No se hace mención alguna a los Cónsules y a los actos de jurisdicción voluntaria mercantiles que son encomendados a los Jueces de Primera Instancia.

En el periodo 1868 a 1881 la regulación sustancial y de trámite de los actos de jurisdicción voluntaria mercantil continúa en el C. Com. 1829 y en la LECNC de 1830 que siguen vigentes. En 1881 se sanciona la LEC que sustituye a la de 1855 y deja sin efecto la LECNC de 1830 y en 1885 el primer C.Com. es sustituido por el de esta fecha.

1-2. La Ley de Enjuiciamiento Civil de 1881. Código de Comercio de 1885. Reformas ulteriores.

La LEC de 1881 dejó sin efecto la LEC de 1855 y la LECNC de 1830 aunque recogió muchas especialidades de esta última. Los procesos mercantiles ordinarios y especiales de la de 1830 pasaron a fundirse y unificarse con los anteriores procesos civiles de la LEC de 1855 aunque se incorporaron especialidades mercantiles como la quiebra, las que derivan de los títulos cambiarios, el juicio ejecutivo mercantil y la jurisdicción voluntaria en negocios de comercio.

Por esta razón los artículos 2109 a 2174 de la LEC de 1881 aparecen por primera vez en esta LEC ya que la de 1855 se refiere sólo a los actos de jurisdicción voluntaria civiles. La expresión etimológicamente quizá no sea la más adecuada pues no todos esos actos tienen 
su razón de ser en un negocio jurídico mercantil. Quizá sea mejor la expresión etimológica, literal, según el sentido de las palabras de actos de jurisdicción voluntaria mercantiles o de comercio.

La expresión jurisdicción voluntaria es también discutible pues existen actos «necesarios» en la jurisdicción voluntaria mercantil para los que ostenta legitimación el Ministerio Fiscal. Es discutible también la expresión jurisdicción. Pero creo conveniente mantener el término en el futuro no sólo por razones históricas que lo justifican, sino por la tradición de la expresión en el derecho Ibero-Americano e Italiano aunque no se justifique con el sentido etimológico y vulgar.

Como se dijo, en la LEC de 1881 los Cónsules recobran la competencia para actos de jurisdicción voluntaria mercantil siempre que les sean solicitados éstos por españoles en los países extranjeros donde hay Consulado Español, y concurran las circunstancias especiales a que se refiere el artículo 2110 LEC. Sin duda debió influir en la atribución de esta competencia la nueva organización y estatuto jurídico de los Consulados Españoles existentes en los países extranjeros con los que nuestra relación era más intensa y que ya dependían del Ministerio de Asuntos Exteriores y que como señala Almagro Nosete esas funciones de los artículos 2109 y ss han seguido vigentes hasta nuestros días.

Pero obsérvese que la LEC al referirse a estos actos siempre se refiere al Código de Comercio de 1829, no al de 1885, por la sencilla razón de ser éste de fecha posterior a la LEC de 1881.

Esto implica que para los actos de jurisdicción voluntaria nuevos previstos en el Código de Comercio de 1885 y en la legislación mercantil especial posterior, no tendrán competencia para acordarlos nuestros Cónsules aunque se tuvieran que acordar o practicar en un país extranjero donde existe Consulado español, salvo disposición expresa. Lo contrario forzaría la interpretación lógica y literal de la LEC de 1881 y se pasaría a una interpretación extensiva y quizá contraria a los postulados legales de la jurisdicción voluntaria. Cuestión diferente es que ligeras modificaciones en los actos de jurisdicción voluntaria previstos en el Código de 1829, a los que se refiere la LEC 1881, fueran actualizados por el Código de 1885 y que por ello pueden seguir siendo objeto de la competencia de los Cónsules siguiendo una interpretación lógica.

1-3. Momento presente o situación actual. La LEC 2000, deja fuera de su regulación los actos de jurisdicción voluntaria sean civiles o mercantiles que siguen contenidos en la ya derogada LEC de 1881 para la 
jurisdicción contenciosa -pero todavía vigente para la jurisdicción voluntaria-. Sólo se hace una referencia a éstos en una Disposición Final que señala que el Gobierno, en ese plazo, presentaría en las Cortes un proyecto de Ley de Jurisdicción Voluntaria que no llegó a la realidad.

La creación de los Juzgados de lo Mercantil, unos años después, nada añade a la competencia de los Cónsules en los actos de jurisdicción voluntaria a salvo de algunas precisiones que seguidamente analizamos.

Prácticamente desde 1881 los actos de jurisdicción voluntaria mercantiles siguen siendo en su contenido y en las consecuencias que a su amparo se pueden solicitar «imperturbables» al no haber sido objeto de modificación o actualización alguna desde dicha fecha por lo que resulta que son verdaderas «reliquias» del pasado de un contrato de fletamento que si entonces tenía razón de ser hoy está totalmente superado y que por esa razón apenas serán solicitados o reclamados ni a los Cónsules españoles en el país extranjero ni a los Jueces de Primera Instancia o de lo Mercantil en el nuestro.

En la actualidad siguen siendo competentes para conocer de los asuntos mercantiles de jurisdicción voluntaria en Primera Instancia los Jueces de este nombre. Cierto que aunque la LEC artículo 2109 se refiere a los Juzgados Municipales en letra cursiva esa referencia lo era a los antiguos Juzgados de Distrito suprimidos y convertidos en Juzgados de Primera Instancia en municipios que cubrían determinado número de población en su circunscripción territorial o fueron suprimidos y su circunscripción agregada a otro de Primera Instancia.

La particularidad de la reciente creación de los Juzgados Mercantiles en el S. XXI y de su jurisdicción y competencia para asuntos de jurisdicción contenciosa o voluntaria en las demarcaciones que se establecen no supone modificación alguna respecto a su inserción dentro del orden civil de la jurisdicción ordinaria.

La tutela judicial mercantil contenciosa o no contenciosa, como señalamos -en la actualidad-, no es jurisdicción especial al formar parte del orden jurisdiccional civil de la jurisdicción ordinaria encomendada a los Órganos citados. Así en primera instancia la competencia corresponde a los Juzgados de lo Mercantil dentro del ámbito de las atribuciones que les confiere la Ley que los crea y en las ciudades donde no se constituyen a los Jueces de Primera Instancia; en segunda instancia ésta corresponde a las Audiencias Provinciales; y 
el TS conoce del recurso casación y del proceso de revisión cuando procedan y que no son admisibles en la jurisdicción voluntaria.

Repito la reciente creación de los Jugados de lo Mercantil sólo supone una especialización por razón de la materia en favor de éstos dentro del mismo orden jurisdiccional civil para la primera instancia en asuntos de jurisdicción contenciosa como de jurisdicción voluntaria mercantil. No supone por ello el establecimiento o la vuelta al sistema anterior de una «jurisdicción diferente, especial y privilegiada» como era la mercantil; señalo de nuevo tanto para la jurisdicción contenciosa como para la voluntaria. La reciente creación de los Juzgados de lo Mercantil en este siglo no afecta tampoco a la segunda instancia que sigue correspondiendo a las Audiencias Provinciales en el orden civil, ni a la competencia del TS en este orden civil para conocer en asuntos contenciosos de los recursos de casación y revisión en materias de derecho mercantil cuando proceden.

Pero el establecimiento de los Juzgados Mercantiles -dentro del objeto de este trabajo- puede tener incidencia en la futura ley de jurisdicción voluntaria si se considera conveniente otorgarles competencia para una homologación mínima (por tanto de intensidad menor al reconocimiento de decisiones extranjeras de jurisdicción voluntaria mercantil para las que también serían competentes) de las decisiones dictadas por los Cónsules o personal diplomático español en esos países extranjeros en el ámbito de la jurisdicción voluntaria mercantil cuando las mismas deban producir efectos en España.

Es decir, sólo en el caso de que en la futura Ley de Jurisdicción Voluntaria se atribuya esta competencia a Cónsules y personal diplomático de Legaciones Españolas en el extranjero y se estableciera que sus decisiones para producir efectos en España deben ser homologadas en un grado mínimo por los Juzgados de lo Mercantil donde existan (donde no por los Juzgados de Primera Instancia) y dentro del ámbito territorial de su circunscripción fijado en la norma que los crea (e incluso si se podría ampliar este ámbito, y sólo a este objeto de homologación, por razón de su especialización a un ámbito territorial mayor como el provincial si existe un juzgado mercantil en la capital de esa provincia o incluso extenderlo a uno mayor como el ámbito autonómico siempre que exista al menos uno en esa Comunidad Autónoma y así equiparar Juzgado Mercantil con el ámbito de una Comunidad Autónoma. Queda claro que si no se les permite ampliar el ámbito territorial de su jurisdicción y competencia en este supuesto ésta correspondería a los Jueces de Primera Instancia del lugar de España donde deben desplegar los efectos jurídicos de la 
decisión dictada por los Cónsules españoles o personal diplomático nacional sito en el país extranjero).

Siempre, suponiendo, que se establezca que las decisiones de los Cónsules dictadas en los países extranjeros donde España tiene Consulado (o del personal diplomático de nuestras Embajadas) y que deben producir efectos en España precisen de esta homologación mínima o reconocimiento por los Jueces de la jurisdicción ordinaria en esa futura Ley de Jurisdicción Voluntaria. Por cierto la LEC de 1881 no dejó suficientemente claro si era o no precisa dicha homologación (que sí exigió a los autos dictados en jurisdicción voluntaria por los jueces de distrito -Justicia Municipal- cuando se creó) por los de Primera Instancia o Mercantil. Es obvio que si sus decisiones o resoluciones plasmadas en el correspondiente auto no precisan de dicho reconocimiento, homologación o ratificación, es decir, si sus decisiones tienen plena eficacia en España sin ningún otro requisito huelga hablar de esta cuestión de reconocimiento y estaríamos ante una competencia exclusiva y objetiva de los Cónsules (sin perjuicio de que tuviera carácter administrativo o jurisdiccional) y no de una competencia funcional en el primer momento, especial y extraordinaria por sus requisitos y a prevención por la urgencia.

Como el lector podrá observar este aspecto de la naturaleza del órgano administrativo o jurisdiccional y la naturaleza de esta competencia objetiva o funcional no es baladí o secundaria si no de suma importancia.

Y esto tampoco puede confundirse -adelantando ideas- ni equipararse con el reconocimiento de las decisiones de jurisdicción voluntaria dictadas por órganos jurisdiccionales o administrativos extranjeros que deban ser homologadas -para desplegar efectos en España- por nuestros órganos jurisdiccionales. Los Cónsules (y el personal diplomático) son órganos españoles y no autoridades extranjeras al depender del Ministerio de Asuntos Exteriores y de exigirse homologación, ratificación o reconocimiento a sus decisiones -por nuestros Jueces- para surtir efectos en España parece que la intensidad de ésta debería ser mucho menor que la exigida a las de los órganos extranjeros, sin perjuicio de lo establecido en los Convenios Internacionales específicos de reconocimiento.

Por lo dicho, si se considera para el futuro conveniente que los Cónsules sigan manteniendo esta competencia deberá dejarse claro en la futura Ley de Jurisdicción Voluntaria -que desconozco si está próxima pese a lo dispuesto en la Disposición Final 18. ${ }^{\circ}$ de la LEC 2000- si su decisión debe estar sujeta a este requisito homologador o no. 
Defiendo que quizá sea conveniente pero con la mínima intensidad siempre que su competencia sea jurisdiccional y no administrativa (de ser así estaríamos ante un supuesto más a añadir a la corriente favorable a la desjudicialización de la jurisdicción voluntaria). Bastaría, si se consagra, con que el auto de jurisdicción voluntaria se remita por conducto diplomático al Juzgado de Primera Instancia o Mercantil competente y éste sin más que proceda -de no observar vulneración alguna en la norma aplicada por el Cónsul- a darla cumplimiento es decir a inscribir el efecto constitutivo en el registro correspondiente y a su notificación a los interesados (efectos constitutivos de la resolución que crea, modifica o extingue situaciones) o a la mera notificación de la resolución a los interesados que sean legitimados directos si es meramente declarativo. Pero si se desea esa desjudicialización de la jurisdicción voluntaria bastaría con equiparar al Cónsul (o como luego veremos el personal diplomático de embajadas) con un Notario y sin necesidad de reconocimiento $\mathrm{u}$ homologación alguna de su decisión.

Cierto que el efecto declarativo de condena no cabe en la jurisdicción voluntaria por la situación de indefensión que originaría a los legitimados directos que no solicitaron el acto de jurisdicción voluntaria y que se encontrarían con una declaración de condena sin haber sido oídos. (Ésta es otra razón por la que la intensidad del control en la decisión de jurisdicción voluntaria del Cónsul debe ser menor al no caber una petición de condena a nadie y además porque el expediente de jurisdicción voluntaria mercantil no produce cosa juzgada con lo que los efectos del auto pueden ser anulados en el proceso de impugnación ordinario en que se hace contencioso dicho expediente por los legitimados directos que no fueron oídos y con todas las garantías constitucionales del proceso consustanciales a la acción y a la jurisdicción.

E igualmente debe dejarse claro en la futura Ley de Jurisdicción Voluntaria si deben ser sólo los Cónsules los únicos competentes para conocer de estos asuntos privados -cuando se les solicite una tutela jurídica concreta de jurisdicción voluntaria mercantil- en el país extranjero donde existe Consulado Español; o igualmente debe ser compartida esta competencia con el personal diplomático de las Embajadas Españolas -se atribuya su decisión al Embajador o funcionarios de éstas- siempre que dispongan del adecuado conocimiento jurídico en la materia. Entiendo que no debería existir inconveniente a ello pues aunque las Embajadas siempre se han ocupado de cometidos de derecho público su función primordial es tutelar los intereses de España y de los españoles que viven en esos Estados extranjeros 
donde España tiene Embajada (sin olvidar la función representativa y mediadora en la relación entre el Estado Español y extranjero) y el fin protector de esos intereses, aunque en la jurisdicción voluntaria mercantil parezcan privados, siempre es público y el mismo que el de esta jurisdicción cuando la asumen nuestros órganos jurisdiccionales.

No se olvide que la distinción originaria de interés privado y público de estos órganos, es decir Consulados y Embajadas Españolas, deviene en la actualidad en artificiosa dado el carácter público de ambos, insertos en el derecho administrativo y con competencias específicas referidas en el ámbito del derecho internacional público.

El origen histórico de la distinción protección de intereses públicos o privados del Estado y de sus nacionales residentes en el estado extranjero donde están sitos es hoy irrelevante y artificioso. Con otras palabras la diferencia en este sentido entre derecho público y derecho privado en el ámbito del derecho internacional responde a otras dimensiones en las que lo público en la mayor parte de las ocasiones envuelve a lo privado. Si se defiende la competencia de los Cónsules y del personal diplomático de las Embajadas que se establezca (con cualificación jurídica suficiente) para los asuntos de jurisdicción voluntaria mercantil debería quedar claro, igualmente, si sólo deberían serlo para los actos de jurisdicción voluntaria mercantil o también para los civiles. Parece que hoy no se comprendería la diferencia del porqué sí de su competencia para los actos mercantiles y el porqué no para los civiles. Defiendo que también para los civiles a salvo de las excepciones que se consideren procedentes.

Sostengo que deberían tenerla para ambos, incluso para aquellos civiles en que fuera precisa la intervención del Ministerio Fiscal pues aunque no está presente en el extranjero, esto se subsana con los medios actuales de comunicación en especial internet donde el correo electrónico y el escaneo de documentos (la solicitud del acto de jurisdicción voluntaria y documentos que la acompañan se envían al Fiscal cuando éste deba intervenir si se inicia a instancia de parte, o éste la envía con tales documentos al Cónsul si dispone de legitimación material para iniciar el expediente de oficio) y el teléfono es casi instantáneo y debe esperar el Cónsul a su dictamen escrito ( remitido por internet y escaneado con firma electrónica del Fiscal) antes de resolver el Cónsul o el personal diplomático; o también se subsanaría dando audiencia al Fiscal -si no lo inició de oficio-, el Juez de Primera Instancia -o de lo Mercantil art. 2111- como trámite preceptivo anterior a la homologación de la decisión del Cónsul o Embajador para que informe de ello en su dictamen escrito. 
Adelantando ideas, debe quedar claro en la futura Ley de Jurisdicción Voluntaria si los Cónsules y el Embajador (o personal diplomático de las Embajadas) en lo concerniente a los actos de jurisdicción voluntaria son órganos jurisdiccionales o administrativos. Es meridianamente claro que para sus otros cometidos son órganos administrativos dependientes del Ministerio de Asuntos Exteriores. Ya me pronuncié defendiendo que se les otorgue a ambos órganos una competencia jurisdiccional delegada si se desea que su cometido de jurisdicción voluntaria sea jurisdiccional; funcional desde la solicitud a su auto; por delegación del poder público; extraordinaria por razones de necesidad especial; a prevención por las razones de urgencia y sujeta a una mera ratificación $\mathrm{u}$ homologación formal por los órganos jurisdiccionales españoles competentes del lugar donde deba desplegar efectos su resolución.

Mantengo esta posición porque entiendo que la jurisdicción voluntaria es un medio de tutela judicial semejante al proceso al ser una manifestación de la heterocomposición pública y encomendada exclusivamente a los Jueces, salvo especial delegación. Difiere del proceso en que no existe contienda, pretensión, contradicción, partes, prueba contenciosa y es provisional ya que no produce la cosa juzgada material del proceso y la formal es limitada y con menor relevancia que en aquél. Por esta razón se permite, posteriormente, en caso de surgir contradicción entre los legitimados materiales directos que no solicitaron esta tutela acudir al proceso y evitar u obviar toda indefensión y que sólo a través del proceso se obtenga el efecto de cosa juzgada.

Soy consciente de que la posición doctrinal que otorga carácter «administrativo» a la jurisdicción voluntaria, aunque lo sea para la defensa de intereses privados que no públicos e insertos en el derecho administrativo (sentado queda que el derecho administrativo es una disciplina de carácter público para la protección del interés público general) es artificial; y que «administrar» un derecho privado especial es antagónico con los principios del derecho administrativo y sólo compatible con el derecho privado; y que pretender equiparar la jurisdicción voluntaria con la función que cumple el derecho administrativo es mucho menos garantista que la posición jurisdiccionalista de la jurisdicción voluntaria especialmente defendida en Italia por Micheli. La jurisdicción voluntaria no es ni puede ser nunca, por su esencia, contenciosa al ser antagónica con ésta pero si equiparamos la jurisdicción voluntaria a la Administración no gozaría la jurisdicción voluntaria de las garantías constitucionales del artículo 24 y 117-3 CE de las que goza la jurisdicción contenciosa 
sin olvidar que los fines de la jurisdicción voluntaria en nada se asemejan a los de la Administración del artículo 103-1 CE sin perjuicio de que a posteriori se encuentre la Administración sometida en sus decisiones administrativas al control de los Jueces y Tribunales, como no podía ser menos. Si la consideramos un medio de tutela jurídica provisional atribuida a los Jueces se puede sostener que la jurisdicción voluntaria es acreedora de ciertas garantías del artículo 24 y $117 \mathrm{CE}$.

De todas formas este trabajo se refiere a los Cónsules en los actos de jurisdicción voluntaria mercantil y no a la jurisdicción voluntaria en general. Por esta razón abordaremos seguidamente los requisitos y el ámbito de las competencias de los Cónsules; su carácter administrativo o jurisdiccional; la conveniencia de extenderla expresamente al personal de embajadas; y terminaremos con una proposición de reforma que podrá influir o no en la futura Ley de Jurisdicción Voluntaria, cuyo nacimiento es incierto, pero que tarde o temprano debería salir a la luz.

\section{Requisitos de su competencia}

La LEC en el artículo 2110 exige unos requisitos de los que se deduce que estamos ante una competencia extraordinaria -la de los Cónsules españoles, en país extranjero, donde exista Consulado Nacional cuando se les solicite por españoles (e incluso, podría defenderse, si existe Tratado, por extranjeros cuando ese Consulado se encargue de la defensa de los intereses de otros países)- a diferencia de la ordinaria del artículo 2109 cuando se reclama ante los Jueces de Primera Instancia o de lo Mercantil.

Sin embargo seguidamente cuando examinemos dichos requisitos se puede llegar a una conclusión diferente, es decir que lo que parece extraordinario o especial se convierte en algo, al menos en apariencia, ordinario. Estos son los que siguen.

2-1. Urgencia en dictar la resolución y adoptar medidas de aseguramiento. La ley habla, de modo impreciso, de urgencia del «negocio». Los supuestos previstos en los artículos 2119 a 2127, 2131 a 2146, 2147 a 2160, 2161, y 2162 a 2174 llevan implícita esta circunstancia y es de carácter objetivo al referirse al buque y a las mercancías. No es de carácter subjetivo. Expresamente lo subraya el Título VII de la segunda parte del Libro III LEC que encabeza los artículos 2162 y ss. «De otros actos de comercio (otros es decir dife- 
rentes a los anteriores) que requieren la intervención judicial (consular) perentoria.» Estos supuestos tienen su justificación en el antiguo contrato de fletamento.

2-2. En el país donde está el Consulado Español estar los medios de prueba o de forma más técnica encontrarse la fuente de prueba o los vestigios materiales que quedan de las mercancías o buque sobre los que se adoptan medidas tras el evento. Sobre la fuente de prueba se practican los medios de prueba (documento, declaración de parte, del testigo, del perito o el reconocimiento judicial) para demostrar los hechos que son su objeto.

Aunque la LEC habla de que «existan» se entiende que se refiere a que se hallen las fuentes y los medios de prueba. Pero como en la jurisdicción voluntaria no existe contienda por esta razón no parece que se pueda hablar propiamente en sentido técnico de prueba si no de justificaciones como señala el artículo 1816 LEC y de «informaciones» de testigos o peritos y de "probanzas» en otros preceptos de la jurisdicción voluntaria. Más que la demostración de la certeza del derecho (aunque sólo sea formal y no material) se busca su verosimilitud, su probabilidad acentuada, el fumus boni iuris de ahí la inexistencia de cosa juzgada y la falta de contradicción en la jurisdicción voluntaria.

2-3. Se encuentren las mercancías o valores -a disposición- del Cónsul para su examen en la población o ámbito espacial del Consulado. Por tanto la fuente de la prueba.

2-4. Los hechos (que originan el siniestro, es decir las manifestaciones o vestigios de éste) hayan ocurrido en el país del Consulado respectivo. Exige una interpretación extensiva ya que los supuestos previstos se refieren a siniestros del transporte marítimo en alta mar. Basta por tanto que ocurra en alta mar el siniestro sea o no ese lugar perteneciente al ámbito espacial de la soberanía del Estado extranjero donde existe Consulado español. Por tanto se pueden solicitar esos actos en el Consulado Español que se crea más adecuado por razón de la cercanía al lugar de producción del siniestro si fue en alta mar y fuera de la soberanía estatal de dicho país o en el país donde resulte más fácil reparar el buque y descargar los efectos transportados si existe Consulado.

2-5. Que el Cónsul en su resolución, la LEC habla de auto, determine o concrete el motivo o motivos de los ya señalados que concurren.

Obsérvese que pese al carácter especial o extraordinario que la LEC desea dar a la competencia del Cónsul detrás de estos supuestos 
concurren circunstancias muy normales o comunes que se resumen en la urgencia objetiva de dictar la resolución y adoptar sus efectos y necesidad de justificar o demostrar prima facie que de no concurrir estas causas sería innecesario el acto solicitado al Cónsul.

\section{3. Ámbito}

Aparecen como señalamos dentro de la Segunda parte del Libro III LEC en los títulos II a VII de la misma, por tanto artículo 2119 a 2174. Su objeto es:

Título II. Depósito y reconocimiento de efectos mercantiles.

Título III. Suprimido su objeto por estar vaciado de contenido.

Título IV. Calificación de las averías y liquidación de la misma y contribución a la misma.

Título V. Descarga, abandono e intervención de efectos mercantiles y fianza del cargamento.

Título VI. Enajenación y apoderamiento de efectos comerciales en casos urgentes y recomposición de naves.

Título VII. Otros actos de comercio que requieren la intervención judicial (consular) perentoria.

Todos estos casos siempre se refieren a supuestos previstos en el Código de Comercio de 1829 y referidos al antiguo contrato de fletamento. Ya dijimos que la LEC de 1881 recoge supuestos previstos en la LECNC de 1830 y se refiere a los sustantivos del código mencionado. No se refiere al Código de Comercio de 1885 que todavía no estaba vigente, sin perjuicio de que los actos de jurisdicción voluntaria mercantil previstos en el C. Com. 1829 modificados por el C. Com. 1885 en lo sustancial se pueden solicitar al amparo de estos preceptos.

Estos supuestos en su mayoría carecen hoy de contenido por razones más sociales y económicas que jurídicas y que resumimos seguidamente. Creo conveniente, señalar sin embargo, adelantando ideas que el antiguo contrato de fletamento -al margen de su discutible vigencia en la actualidad-, quedó vaciado de contenido por el contrato de seguro concertado entre la empresa transportista y la sociedad aseguradora o entre la empresa cargadora y la sociedad aseguradora y al que se suele hacer mención como anexo en las cláusulas del contrato de transporte marítimo realizado entre ambas empresas, seguro que se incluye o excluye dentro del precio de 
la prestación y que viene a ser -sin que sea obligatorio el seguro- el sistema más frecuente en esta contratación. En ocasiones la empresa cargadora hace constar como cláusula que la mercancía ya está asegurada para reducir el precio del transporte. La falta de seguro conlleva los efectos del riesgo y quien lo asume que de no señalarse nada y de no imponerse el seguro obligatorio por el Estado en tal transporte serían del cargador -a salvo de disposición expresa en contrario por la normativa de éste-. Sólo en el caso de un contrato de transporte marítimo expresamente estipulado bajo las condiciones del antiguo contrato de fletamento quedan justificadas estas especialidades de los artículos 2119 y ss. LEC dentro de la libertad de contratación establecida en el CC, y CCom. o cuando se mantenga como costumbre entre los contratantes dicho régimen basado en el antiguo fletamento.

Cuando entró en vigor la LEC 1881 el transporte más importante era el marítimo y por ello no se hace referencia en estos preceptos al contrato de transporte terrestre que sólo podía hacerse en carros de tracción animal o por ferrocarril ni a los actos de jurisdicción voluntaria de él derivados. El transporte marítimo era más rápido que el terrestre, más barato, era transoceánico, admitía un cargamento muy superior e incluso podría afirmarse, aunque sea discutible, que más seguro. Tampoco se refiere al transporte aéreo al ser desconocido en ese momento.

La razón es obvia, en 1881 todavía no existían los vehículos de motor es decir coches y camiones que aparecieron unos años después. El ferrocarril era escaso, caro y no era internacional. Tampoco existía el avión que aparece varias décadas después y es mucho más rápido y adecuado para objetos de poco volumen y gran valor que el transporte marítimo. Solo existía como transporte terrestre carros con tracción animal, y el ferrocarril muy caro y sin proyección internacional debiendo añadirse el costo añadido por impuestos que el pago en cada aduana representaba.

En 1881 vigente la LEC el riesgo al siniestro en el transporte marítimo era muy grande al golpe de mar, por el tipo de barcos existentes a vela o vapor menos seguros que en la actualidad, y esto dificultaba el contrato de seguro apenas existente y las compañías aseguradoras eran de menor relieve y con escaso poder económico para asumir la responsabilidad derivada del seguro. De ahí el sistema establecido de riesgo a prorrata del fletamento o de compensación de riesgos de las mercancías entre los diferentes cargadores. Desde mediados del S. XX nada es igual. 
Además el seguro lleva consigo la subrogación de las Compañías Aseguradoras en la posición jurídica del porteador y/o cargador al consagrarse la acción directa en su favor lo que implica la subrogación material del asegurador en la posición jurídica del asegurado frente a reclamaciones a terceros también denominada sustitución en la legitimación material y/o sustitución procesal. Esto hace casi innecesaria esta regulación decimonónica. Pero además no podemos olvidar que las Compañías Aseguradoras en el transporte marítimo tienen carácter internacional y disponen de empresas subcontratadas a su servicio, grandes naves o espacios para guardar mercaderías, y que pueden dar una rápida y perfecta salida a las mercancías cuyo buque fue objeto de un siniestro de cualquier tipo.

Devendría innecesario el reconocimiento de los efectos o mercaderías por el Juez o Cónsul; el nombramiento de peritos titulados o prácticos que después determinan el estado en que se encuentran; hacer su inventario; llevar a cabo su depósito necesario judicial -o consular-. y buscar el lugar adecuado dependiendo de las dimensiones del cargamento; proceder a su avalúo en caso de ser necesaria su venta total o parcial dependiendo de que sean productos perecederos, o no, sea necesaria su venta para el pago de averías, de la descarga, o para pagar en parte la pérdida de la nave ..... por los peritos para determinar su importe y fijar el precio de salida para una primera subasta voluntaria y caso de no cubrirse el importe rebajarlo y proceder a ulteriores subastas; depositar el valor del dinero obtenido en los establecimientos adecuados de ese país extranjero hasta el pago a quien corresponda, en ocasiones parte de este dinero obtenido sirve de préstamo al capitán para el arreglo de la nave.... Todo esto es innecesario pagando la compañía aseguradora el importe asegurado en caso de siniestro, subrogándose en la posición del asegurado y el ejercicio de las acciones directas por las compañías aseguradoras cuando proceda y contra quien proceda.

Si los efectos son de diferentes cargadores es innecesario con la acción directa determinar, según las mercaderías deterioradas, cual debe ser la parte proporcional de riesgo que deben asumir los cargadores que no sufrieron la pérdida. O como deben contribuir o en que proporción en caso de avería de la nave o arribada forzosa para su reparación y gastos de descarga de mercancías y lugar del depósito y posible venta. O constatar mediante informaciones de testigos que sean personal del buque o viajeros o en forma documental o en los libros correspondientes que la conducta del capitán fue la correcta ante esas situaciones y debe ser eximido de toda responsabilidad. 
Todo esto es pasado superado; totalmente antagónico con los tiempos presentes; con el propio derecho mercantil e internacional público y el papel de un Cónsul. Se suple con el contrato mercantil de seguro y las ventajas de la acción directa que supone la subrogación o sustitución del asegurador en la legitimación material del asegurado frente a terceros.

Repito razones sociales, económicas, uso de otros instrumentos jurídicos como el contrato de seguro dejan sin contenido estos supuestos por lo que no debe de extrañar al paciente lector que los Cónsules lleven a cabo muy pocos expedientes de jurisdicción voluntaria mercantil como los referidos. Acaso sólo para un transporte marítimo de mínima entidad y donde se deje claro que la mercancía se transporta sin seguro y al amparo de las disposiciones de los Códigos de Comercio de 1829 y 1885.

La realidad social de los tiempos actuales en que deban aplicarse estas normas las han dejado vaciadas de contenido. Su espíritu y finalidad entiendo que ha quedado vaciado de contenido. Basta con derogar los preceptos mencionados 2119 y ss LEC y establecer que: «En caso de siniestro en cualquier supuesto de transporte terrestre, marítimo o aéreo el Cónsul y personal diplomático, de conformidad con las autoridades del Estado de ese país y sin invadir sus competencias exclusivas, adoptarán como actos de jurisdicción voluntaria mercantil las medidas de aseguramiento y prevención solicitados por los interesados, muy especialmente las solicitadas por las compañías de seguro en el ámbito de su acción directa».

\section{Clasificación}

Debe destacarse que los actos de jurisdicción voluntaria en asuntos de comercio que pueden llevar a cabo los Cónsules son casi los mismos que competen al Juez de Primera Instancia o al Juzgado de lo Mercantil aunque su ámbito es algo más reducido al existir en la LEC de 1881 algunos no atribuidos a los primeros y los requisitos especiales que concurren en los Cónsules. Si la futura reforma les sigue otorgando competencia debería tener en cuenta la realidad social a que me referí en el anterior número 3.

Siguiendo la clasificación de Almagro Nosete, pero ciñéndome sólo a los actos de jurisdicción voluntaria mercantil de los Cónsules en la LEC 1881 referidos o derivados del contrato de fletamento, se puede hablar de:

4-1. Actos declarativos de derechos de carácter constitutivo (así los dirigidos a la formalización de negocios jurídicos como la 
consignación del importe de la subasta; consignación del importe de efectos mercantiles, consignación de fianza, autorizaciones para realizar actos o negocios jurídicos como descarga y carga en caso de arribada forzosa, licencia para contraer préstamo a la gruesa, licencia para abrir las escotillas del buque. Es dudoso si hoy pueden conocer los Cónsules de la denuncia de robo, hurto o extravío de documentos de crédito o efectos al portador para impedir que se pague su importe o en caso de extravío, sustracción o destrucción de la letra de cambio).

4-2. Actos declarativos de derechos de carácter no constitutivo (semejantes a procesos declarativos como la calificación de averías, abandono de género para pago de portes).

4-3. Actos que implican medidas de prevención para la salvaguarda de derechos, semejantes a diligencias preliminares (recomposición de naves, exhibir el libro de navegación), semejantes a medidas cautelares (intervención de efectos mercantiles, depósito judicial necesario de mercaderías o efectos mercantiles, fianza del valor de cargamento), semejantes a pruebas anticipadas (reconocimiento de efectos mercantiles, información de hechos en caso de requisa de víveres, acreditamiento de causas de avería de una nave).

4-4. Actos que implican mandatos de ejecución como autorizar la subasta judicial necesaria o forzosa (enajenación y apoderamiento de efectos comerciales en casos urgentes, venta de efectos procedentes de un siniestro) o autorizar subastas voluntarias en caso de autorización expresa en las cláusulas del contrato de fletamento al capitán por cargadores aunque es discutible.

Por el contrario, si los clasificamos en relación con el ulterior proceso a seguir, en caso de que el expediente pudiera devenir contencioso, sugerimos la clasificación de actos de mera declaración, actos constitutivos y actos de aseguramiento. En este caso surgido el proceso estaríamos ante pretensiones de mera declaración, pretensiones constitutivas destinadas a crear, modificar o extinguir una situación creada o no por ese acto y pretensiones de oposición a la práctica de actos de conservación o aseguramiento que implicaban mandatos de ejecución sobre uno o más bienes para obtener la paralización y la indemnización de daños y perjuicios. 


\section{Naturaleza jurídica y carácter de los Cónsules en la jurisdicción voluntaria}

Aunque los términos naturaleza jurídica y carácter no son sinónimos, existe una gran semejanza. No es éste el momento de entrar en sus analogías y diferencias ya que entraríamos en disquisiciones doctrinales por lo que en este epígrafe dadas sus semejanzas utilizo ambos términos de forma análoga. Queda claro el uso del término.

El Código de Comercio de 1829 y la LENC de 1830, siguiendo la legislación precedente, tenían claro que los Cónsules son un órgano jurisdiccional cuando actúan como tales en los asuntos de jurisdicción contenciosa y voluntaria mercantiles en los que era requerida su jurisdicción que era especial y privilegiada. Tenían un carácter privado aunque la función jurisdiccional es pública y no tenían carácter permanente. No es objeto de este estudio, pues excede su límite, examinar el carácter de otras funciones que desempeñan los Cónsules durante el S. XIX.

El Decreto de 1868 deja clara la supresión de esta jurisdicción especial; desaparece el cometido jurisdiccional de los Cónsules ya de jurisdicción contenciosa como voluntaria y su función es asumida por la jurisdicción ordinaria. Situación que mantiene la LOPJ (que siempre fue provisional, aunque llegó a centenaria) de 1870, al no hacer alusión alguna a los Cónsules que no forman parte de la jurisdicción ordinaria y sus funciones las asumen los Jueces de Primera Instancia que forman parte de ésta. Situación que se mantiene hasta 1881.

Es desde 1881 cuando surge la confusión pues la LEC de esta fecha confiere los asuntos de jurisdicción voluntaria mercantil (impropiamente habla de actos de negocios de comercio) a los Cónsules sin modificar la LOPJ de 1870 que los silenciaba, situación que mantiene la vigente LOPJ de 1985 que tampoco hace alusión a los Cónsules.

Si en 1868 se suprime la jurisdicción mercantil especial y privada, de forma análoga los Cónsules dejan desde entonces de ostentar la condición de personas privadas y pasan a ostentar la condición de públicas al ser funcionarios, en los Consulados Españoles sitos en el extranjero, dependientes del Ministerio de Asuntos Exteriores.

Podría defenderse el carácter administrativo de los Cónsules en el ejercicio de esta función ya que no se refiere a éstos la LOPJ de 1870 ni la de 1985 y sí se refieren a los Jueces de Primera Instancia -y tras sucesivas reformas de la de 1985 a los Juzgados Mercantiles- en los actos de jurisdicción voluntaria mercantil con igual cometido y 
contenido; porque son funcionarios públicos dependientes de dicho Ministerio; porque sólo tienen esa función residual de jurisdicción voluntaria para estos actos en casos especiales y en el extranjero si España en ese país tiene Consulado. En ese caso su resolución no debería ser una resolución jurisdiccional con forma de Auto como señala la LEC 1881 si no una resolución administrativa que integra el acto administrativo y susceptible de recurso de alzada ante el Ministerio de Asuntos Exteriores -o ser expresamente inimpugnable si así se estableciera- lo que silencia la LEC 1881.

Puede defenderse el carácter jurisdiccional de los Cónsules en el ejercicio de este cometido siempre que admitamos que en la jurisdicción voluntaria el Juez o Cónsul aplican el derecho al caso concreto y que es un medio de tutela jurídica específica diferente de la contenciosa en el que en ningún caso se busca alcanzar el efecto de cosa juzgada. (La jurisdicción voluntaria aunque sea jurisdicción en ningún caso es jurisdicción contenciosa ni pretende alcanzar sus efectos, pero puede necesitar para su desempeño de las garantías constitucionales del artículo 24 y 117-3 CE).

Quizá este fuera el deseo del legislador de la LEC de 1881 y por ello al referirse a los Cónsules habla de Auto en vez de resolución; silencia el recurso que procede contra él y ante qué órgano procede; y parece «desear» aunque no se consagra expresamente la obligatoriedad -como se decía con los jueces municipales y de distrito- de que su «auto» debía ser homologado, revisado, examinado en cuanto ajustado al derecho nacional por el juez de primera instancia del lugar donde deba producir efectos en España. Es decir no recurso, pero sí homologación en todo caso, que sería el remedio al recurso, existiera o no gravamen para los solicitantes de esta tutela, sin perjuicio de que luego los interesados hicieran contencioso el expediente.

Si este era el deseo del legislador de 1881 y éste el régimen a seguir se exigiera -o no- tal homologación estaríamos ante una competencia jurisdiccional de los Cónsules, por delegación legislativa del Poder del Estado ya que la concede al Cónsul el legislador y así lo proclama la LEC de 1881; de carácter especial para supuestos en que se solicitan actos -fuera de España- al Cónsul si en el país extranjero existe Consulado, a prevención porque en todos esos supuestos concurre una situación de urgencia objetiva que exige evitarla. Si además se exige la homologación en todo caso dicha competencia del Cónsul sería funcional y sólo dentro del primer momento o fase inicial de la primera instancia y sujeta a un 
control o examen, a homologación, es decir sujeta a ratificación por el Juez de Primera Instancia o Juzgado de lo Mercantil competente. Y en cuanto acto jurisdiccional sujeto a las garantías del artículo 24 y 117 CE pero a partir de la fase de ratificación a cargo de estos últimos.

Me parece más garantista esta segunda interpretación, acorde con la historia y el sentido de la función de la jurisdicción voluntaria, que es un medio de tutela jurídica diferenciado del proceso. Creo que el legislador de 1881 tenía en mente esta segunda interpretación. En los tiempos actuales si se decide mantener la competencia de los Cónsules y/o del personal diplomático en los actos de jurisdicción voluntaria mercantil es más garantista esta concepción jurisdiccional de la jurisdicción voluntaria que la administrativa que implica o lleva a su desjudicialización para administrar meros intereses privados a través de funcionarios públicos so pretexto de que gozan de la fe pública. Sé que existe una tendencia doctrinal actual con muchos seguidores defensora de la desjudicialización de muchos actos de jurisdicción voluntaria y dotarles de carácter administrativo aunque sea para la «administración del derecho privado» (lo cual es antagónico con la concepción del interés general del derecho administrativo) pero que por la necesidad de otorgarles la fe pública a estos actos puede justificar la «publificación del derecho privado» sólo por esta razón. De ser así pueden asumir la fe pública cualquier funcionario administrativo como los Notarios, Registradores, Secretarios Judiciales, Personal administrativo, Cónsules y porqué no el personal diplomático de las embajadas. Pero no es óbice a esto, que puedan asumir funciones jurisdiccionales a través del instrumento de la delegación jurisdiccional como ya señalé otorgándoles una competencia funcional especial o extraordinaria, a prevención y sujeta a ratificación u homologación del Juez ordinario.

No se olvide que la esencia de la jurisdicción voluntaria no es que sea impartida necesariamente por el Juez u órgano jurisdiccional (teoría subjetiva), si no que se trata de un medio especial de tutela jurídica diferenciado del proceso y diferenciado de la propia autotutela de la administración (Teoría objetiva de la jurisdicción voluntaria). Que el Cónsul, órgano administrativo, asuma una función jurisdiccional sólo en el ámbito de la jurisdicción voluntaria por delegación del Estado para ese fin no supone negar que tenga doble carácter administrativo para actos administrativos en defensa 
o para tutela de intereses públicos y jurisdiccional para los actos de jurisdicción voluntaria.

Obsérvese la importancia de esta cuestión; obsérvese que no es cuestión baladí la naturaleza de la resolución jurisdiccional o administrativa que dictan por ser sus efectos diferentes; incide en la admisibilidad o no del recurso contra la misma; de la posible intervención o no del Ministerio Fiscal -sea de oficio o a instancia de parte cuando proceda- en el procedimiento que se siga ante los Cónsules de concurrir en el acto que se les solicita el interés de menores, incapaces, ausentes o personas desvalidas; incide en el control de su decisión allí donde debe producir efectos en caso de precisar en España de actos ejecutivos indirectos de constancia sin perjuicio de su deber de respetar las competencias exclusivas del país extranjero en cuestión donde está sito el Consulado.

\section{Procedimiento. Libertad formal. Recurso}

La LEC apenas hace referencia al procedimiento a seguir por el Cónsul cuando se le solicita la adopción de actos de jurisdicción voluntaria mercantiles para producir consecuencias jurídicas específicas.

El artículo 2111 señala que las normas de procedimiento para las actuaciones que se soliciten en España ante los Jueces de Primera Instancia son las que establezca el Código de Comercio (o la ley material que la contiene) si son especiales para el acto específico en cuestión. Y en su defecto son las establecidas en el artículo 2111 y los que siguen hasta el 2126 LEC y las de la presente Ley es decir las de los artículo 1811 a 1824 LEC de los actos civiles de jurisdicción voluntaria e incluso otros preceptos de la jurisdicción contenciosa según el artículo 1824 LEC. Pero no especifica las normas de procedimiento a seguir en las actuaciones de los Cónsules pues el artículo 2127 LEC se refiere de forma lacónica, fragmentaria y lagunosa a esta cuestión bajo la expresión de que los Cónsules "procurarán» ajustarse, «en lo posible» a las prescripciones de esta Ley. Por tanto remisión si les es posible a los artículos 2111 a 2126 mencionados y 1811 a 1824 LEC y según este precepto a toda la LEC.

Debe tenerse en cuenta que en este procedimiento para la adopción de actos de jurisdicción voluntaria mercantil rige el principio de libertad formal a que se refiere el artículo 1816 LEC «sin solemnidad alguna» tanto para la presentación de documentos como para pedir 
justificaciones sin que se produzca preclusión alguna antes de dictarse la resolución definitiva; y el artículo 1818 LEC que permite al juez «variar o modificar las providencias» de mero trámite, es decir las resoluciones que dicte de mero trámite que no son definitivas, sin sujetarse a especiales requisitos. Consecuencia de ello es el principio de subsanabilidad de las actuaciones Artículo 2111-5. ${ }^{\circ}$ Queda fuera el Auto al tener el carácter de resolución definitiva y por ello producir el efecto de cosa juzgada formal que sin embargo se queda en casi nada al poderse convertir en cualquier momento el expediente en contencioso acudiendo al proceso.

Se prevén unas reglas que aunque parecen especiales son generales así:

- Audiencia a los legitimados directos, previa citación a la vista, para que aleguen lo oportuno que evite un perjuicio en sus intereses. Artículos 1813, 1814 y 2111-1.

- Permitir la asistencia de personas con legitimación indirecta a la vista, si tienen interés en los efectos jurídicos solicitados por los que iniciaron el expediente ya que puedan resultar afectados o perjudicados por la resolución definitiva o auto. El objeto es que aleguen lo oportuno a efectos de obviar o impedir este perjuicio. 2111-1. ${ }^{\circ}$

- Sólo pueden solicitar actuaciones los que tengan legitimación e interés directo en el acto solicitado rechazándose de plano las pedidas por quien no tenga interés directo o indirecto, es decir legitimación sobre los efectos jurídicos pretendidos en ese asunto. 2111-1. ${ }^{\circ}$

- Se puede solicitar una única actuación o varias de jurisdicción voluntaria. Acumulación inicial. Lo que no se puede es acumular actuaciones de jurisdicción voluntaria a asuntos contenciosos en curso (fueran o no, estos procesos, actuaciones de jurisdicción voluntaria anteriormente) de conformidad con el artículo 1823 previsto para la jurisdicción voluntaria civil de aplicación a la mercantil y de la misma forma a las actuaciones de los Cónsules.

- Deberá citarse al Ministerio Fiscal, prevé la LEC, en los asuntos seguidos en España ante el Juez o Juzgado a instancia de interesados, acompañando con la citación copia del expediente (o manifestación de que puede examinarlo en el lugar determinado para ello) para que pueda ser oído en la comparecencia y que entregue en ésta o emita después un dictamen escrito si la actuación solicitada afecta a intereses públicos o a intereses de menores, incapaces, ausentes o personas desvalidas. 1815 y $2111-2 .^{\circ}$ LEC. Si lo inició el Fiscal de oficio, la copia del expediente se entrega a los interesados. 
Si se sigue el procedimiento ante Cónsules es discutible si es preceptiva la intervención del Fiscal y si se le remite copia de la solicitud y documentos por conducto diplomático y se espera por los Cónsules a que remita por esta vía su dictamen el Ministerio Fiscal, o si se puede enviar esta documentación directamente mediante fax o e-mail escaneando los documentos en espera que éste lo haga por esta vía; o si para la resolución del Cónsul o Auto no es necesaria la intervención del Fiscal y sí para la homologación. Ya me referí parcialmente.

Si se afirma que no es preceptiva en tal caso la intervención del Fiscal por seguirse esta actuación ante los Cónsules y no existir en el país extranjero del Consulado Fiscales Nacionales es discutible si debe defenderse que el Auto de los Cónsules debería ser homologado por el Juez de Primera Instancia previa audiencia al Ministerio Fiscal y examen de su dictamen como trámite previo si seguimos una interpretación extensiva del artículo 2111-7. ${ }^{\circ}$ o es innecesario homologación alguna sin perjuicio de que se pueda hacer contencioso el expediente. Ver lo dicho en naturaleza y carácter.

- El Cónsul -tras la presentación de la solicitud en que se solicita el acto de jurisdicción voluntaria acompañada de los documentos que lo justifican-, por providencia citará a los legitimados directos, a los que tengan un interés indirecto sin ser legitimados directos, y a los testigos que den informaciones les apercibirá que acompañen a la comparecencia los documentos que acrediten su identidad y en su caso su capacidad jurídica pues los que justifican la legitimación e interés directo de los solicitantes del acto se acompañan con la solicitud. Artículo 2111-3 y 4 LEC. De su resultado artículo 2111-3. ${ }^{\circ}-2$ se dejará constancia en el acta de la vista oral.

Lo mismo se hará con los peritos, artículo 2117, que propongan los interesados que deberán ser titulados si los hubiere y si no prácticos, sin perjuicio de que su dictamen verse sobre avalúos o inventarios o tenga otro contenido. Se acompañará si es posible el dictamen con la solicitud y documentos, y de no ser posible se aportará en la comparecencia y será en ésta donde explicarán al Cónsul el objeto o razón de ser de su dictamen.

- La LEC no impide al Cónsul que proceda a un reconocimiento judicial presentada la solicitud que podrá llevar a cabo antes de la comparecencia, con ocasión de esta o con posterioridad en base al principio de flexibilidad procedimental.

De lo dicho hasta el momento, queda reflejado el trámite de la solicitud y su contenido más los documentos que la acompañan, 
la providencia del Cónsul teniéndola por presentada con esa documentación en que se acuerda citar a los solicitantes del acto, demás interesados, peritos, testigos a una comparecencia. En la citación se hará constar lugar, día y hora en que tendrá lugar y la prevención de la necesidad de su identificación a efectos de que quede esta determinada, y de ser posible acreditar su capacidad de obrar y de que la solicitud y documentos presentados están en el Consulado a disposición de los interesados los días y horas que se determinan para su examen o el día de la celebración de la comparecencia antes de ésta.

En el contenido de la solicitud dirigida al Cónsul se señalarán las personas que solicitan el acto, su contenido y efectos jurídicos que se solicitan a su amparo, debidamente fundamentada, subsumiendo los hechos ocurridos y los efectos jurídicos solicitados en el presupuesto fáctico de la norma jurídica material y/o de trámite y los efectos en éstas previstos. Debe concretarse que concurren las circunstancias especiales que justifican la competencia del Cónsul y especificarlas.

Se especificarán con el nombre y apellidos las personas que tiene interés en el asunto y que deben ser citadas; que se cite al Ministerio Fiscal si concurre el interés público o afecta la decisión a menores, incapaces o ausentes; nombre y apellidos de los peritos titulados -O no titulados, en defecto de aquéllos- para que informen; nombre y apellidos de las personas que ofrecerán la información testifical; en su caso solicitar el reconocimiento consular del buque y mercaderías, de considerarse procedente. De existir documentos que no pueden acompañarse, señalar éstos y lugar o archivo donde se encuentran para que puedan ser remitidos por conducto diplomático o directamente por fax o por internet escaneados debidamente.

La comparecencia comenzará con un breve resumen del Cónsul de las actuaciones seguidas en especial de la solicitud y documentos presentados con ésta, ulteriores documentos presentados por otros interesados; seguirá dando la palabra a los solicitantes para que se ratifiquen en lo pedido (-si se sigue el trámite oral-, pues si es escrito y no existe inmediación huelga todo esto), a los demás interesados para oír sus manifestaciones aunque su oposición no puede ser determinante al carecer el Cónsul de jurisdicción para asuntos contenciosos si quieren hacer contencioso el expediente, a los testigos para que presten la información testifical según lo percibido por los sentidos y finalmente al perito para que informe oralmente de su dictamen ya presentado o que presenta en la comparecencia y a las preguntas que se le formulen y requieran sus especiales conocimientos técnicos sea o no titulado. Respecto al Fiscal, si se exige su dicta- 
men escrito, que no es vinculante al Cónsul, manifestar si se recibió o no por fax o por documento escaneado en internet a efectos de que los interesados hagan manifestaciones. Y si no se recibió esperar un tiempo prudencial a su recepción, dando sólo traslado de éste a los interesados como trámite previo para dictar el auto.

Puede procederse en el momento inmediato anterior a la comparecencia, durante ésta interrumpiéndose momentáneamente o en el momento inmediato posterior a un reconocimiento del Cónsul del buque o del lugar donde se encuentren los bienes muebles (equivale al reconocimiento judicial). Previamente podrá solicitar a efectos de las probanzas a realizar en la comparecencia el auxilio y cooperación judicial internacional que precise en especial del país extranjero donde está el Consulado.

La comparecencia de establecer el Cónsul la forma oral podría grabarse; y si el trámite seguido es escrito o de audiencia formal puede testimoniarse lo acaecido, artículo 2111-6. ${ }^{\circ}$ LEC. Me remito a lo dicho en la flexibilidad formal.

Finalizada ésta procederá a dictar el Cónsul el Auto para el que no se prevé plazo alguno. Artículo 2110-2. ${ }^{\circ}$ Podría ser inmediato al final de ésta si dispone de elementos necesarios y no interviene el MF en las actuaciones o tardar un plazo no muy largo, aunque la falta de contienda y el acuerdo de consuno de los solicitantes, conlleva que no se dilate. Entiendo que inferior al mes.

Es importante destacar que el artículo 1817 LEC no es de aplicación al Cónsul por tanto no es de aplicación a las actuaciones de los artículos 2109 a 2118, por lo que los interesados que no solicitaron esas actuaciones no pueden hacer contencioso en la comparecencia el expediente ante el Cónsul por la sencilla razón de que carece de jurisdicción para el trámite mercantil contencioso. Pero sí podrán manifestar su deseo de hacerlo contencioso ante las autoridades judiciales extranjeras de ese país o ante las españolas, y en ese caso si el Cónsul dictó el auto acordando dicha actuación solicitar en la demanda del proceso principal la suspensión de esos efectos.

Es discutible si contra el Auto del Cónsul procede o no recurso y todo dependerá de la naturaleza jurídica del cónsul según se considere órgano administrativo o jurisdiccional (de jurisdicción voluntaria que no contenciosa como señalamos respecto al art. 1817).

Si se considera órgano administrativo dependiente del Ministerio de Asuntos Exteriores procedería el recurso administrativo ordinario previsto es decir el de alzada ante este Ministerio (a salvo que esté 
expresamente excluido lo que en este momento desconozco) el cual sería estéril pues cualquier interesado haría contencioso ese expediente ante los Jueces de Primera Instancia Españoles o las autoridades judiciales competentes del país en cuestión donde se produjeron los hechos o repetiría esa petición por el trámite de jurisdicción voluntaria en España pues la cosa juzgada formal, obviada la urgencia que justifica la actuación del Cónsul, queda desnaturalizada.

Si se considera un órgano jurisdiccional entiendo que no cabe recurso alguno, pues carece de sentido un recurso de apelación ante la Audiencia Provincial que sí procede cuando conocen los Jueces de Primera Instancia o de lo Mercantil. Además ello se confirma con el silencio legal en este caso que no se produce en caso de los anteriores.

Bastaría con la mera homologación de su resolución como sucedía con los autos dictados en esta materia por los jueces municipales y de distrito, es decir sin otro trámite ni comunicación a los interesados desde la recepción de las actuaciones seguidas ante los Cónsules -por conducto diplomático del MAE al Ministerio de Justicia y de éste al Juez de Primera Instancia o Mercantil del lugar donde deben producir efectos y Auto reconociendo su contenido si se ajusta a la legalidad o modificándolo para ajustarlo a éste. Y se confirme o modifique se comunicaría el Auto homologador a los interesados.

Sólo si no se siguió el trámite de audiencia al MF -si concurre el interés publico o el de personas menores, incapaces, ausentes o desvalidas-, por el Cónsul de no ser preceptivo lo que no concreta la LEC se le concederá audiencia para el examen de las actuaciones seguidas ante Cónsules y que emita dictamen escrito sobre su legalidad, y seguidamente dentro del plazo común dictar el Juez de Primera Instancia o de lo Mercantil el auto que homologa su resolución o auto (igualmente) del Cónsul confirmándolo, modificándolo o incluso revocándolo y se comunica éste a los interesados.

En este caso sí cabría contra este auto del Juez de Primera Instancia o de lo Mercantil que lo homologa recurso de apelación, siguiendo la regla general, ante la Audiencia Provincial aunque en ningún caso el recurso especial de casación, ni los procesos impugnativos autónomos extraordinarios de revisión ni el de audiencia al rebelde. Es discutible como se dijo si procede o no esa homologación que la LEC no deja clara.

En conclusión contra la resolución del cónsul no cabe recurso de apelación directo ante la Audiencia Provincial y no son de aplicación 
los artículos 2112 a 2116 LEC, ni los artículos 1819 a 1821 LEC. Es discutible si es admisible o no la homologación del auto del Cónsul y de serlo lo sería ante el Juez de Primera Instancia o de lo Mercantil que confirma o modifica la decisión del Cónsul y contra éste cabría apelación ante la Audiencia Provincial.

Si no se admite homologación, la decisión del Cónsul es firme formalmente y produce cosa juzgada formal pero de efectos muy atenuados porque desde ese momento los interesados que no solicitaron las actuaciones, y no se les dió audiencia y se ven perjudicados pueden impedir esos efectos por vía de jurisdicción voluntaria a los Jueces desaparecida la urgencia (entiendo que es admisible por el carácter especial del Cónsul, aunque discutible) o acudiendo al proceso haciendo contencioso el expediente presentando la demanda que corresponda ante el Juez de ese país donde existe Consulado Español o ante los Jueces Españoles competentes y además solicitar en ella como medida cautelar la suspensión de esos efectos y en su caso la indemnización de daños y perjuicios. Si se presenta ante el Juez del país extranjero el auto o sentencia firme que dictó en su día, si se desea que produzca efectos en España, deberá ser reconocido por los Jueces Españoles siendo de aplicación los Tratados Internacionales suscritos por España sobre reconocimiento de sentencias y decisiones extranjeras.

\section{LÍNEAS DE LA FUTURA REFORMA A MODO DE CONCLUSIONES}

PRIMERA. La reforma de la jurisdicción voluntaria mercantil en la futura Ley que regule sus actos debe ajustarse a la realidad social del tiempo en que ha de ser aplicada. Las normas vigentes en lo sustancial y en el trámite son obsoletas. La razón estriba en que los actos previstos en los artículos 2119 y ss han quedado vaciados de contenido por razones sociales y jurídicas, ya que el contenido del transporte marítimo se realiza por grandes compañías de transporte que a su vez lo son de transporte marítimo, terrestre y aéreo y éstas a su vez contratan con compañías aseguradoras internacionales el posible riesgo derivado de un siniestro. El transporte marítimo no es el único importante, pues a él se suman en semejante medida el aéreo y terrestre.

Mi trabajo se refiere a los supuestos de competencia de los Cónsules en los actos de jurisdicción voluntaria y a ello se refieren mis pro- 
puestas. Este trabajo no se refiere a la jurisdicción voluntaria en los «negocios» de comercio, aunque conlleva muchas sendas paralelas.

SEGUNDA. Entiendo que tanto los Cónsules como el personal diplomático de embajadas con la cualificación jurídica requerida, debe tener competencia en el ámbito de los actos de jurisdicción voluntaria tanto civil como mercantil.

TERCERA. Su competencia objetivamente debe cubrir los mismos supuestos - O casi todos- que la que tienen los Jueces de Primera Instancia o de lo Mercantil Españoles en las actuaciones civiles o mercantiles cuando se solicitan en España.

CUARTA. Las actuaciones de jurisdicción voluntaria que deban realizarse o practicarse en el extranjero, solicitadas por españoles, deberán ser practicadas por los Cónsules Españoles y el personal diplomático de las Embajadas Españolas que se determine siempre que España tenga Legación Consular o diplomática en ese país extranjero donde se les recaban y siempre que no se invada por éstos las competencias exclusivas del país en cuestión.

QUINTA. Lo afirmado en la propuesta anterior lo es sin perjuicio de que los interesados españoles tanto donde existan Consulados o Legaciones Españolas como donde no pueden recabar esas actuaciones de jurisdicción voluntaria de las autoridades administrativas o judiciales extranjeras -dada la perentoriedad en muchos casos de las actuaciones de jurisdicción voluntaria- como de las judiciales españolas, sin perjuicio de que si las recaban de las extranjeras será necesario su reconocimiento en España de conformidad con los Tratados Internacionales de reconocimiento y homologación de decisiones extranjeras.

SEXTA. El procedimiento a seguir por los Cónsules y Personal diplomático de las Embajadas Españolas debe ser único para todos los actos de jurisdicción voluntaria civiles o mercantiles, que les sean solicitados y el mismo que el seguido en España para las actuaciones de jurisdicción voluntaria de ámbito nacional que formen parte de las competencias exclusivas del Estado Español. (Todas las mercantiles y las civiles no excluidas). Sin embargo los actos de jurisdicción voluntaria que formen parte de las competencias exclusivas asumidas por las CCAA que integran el Estado Español (derecho civil histórico foral o autonómico foral desde su constitución como CA conforme a su Estatuto de Autonomía) podrán ser solicitados a éstos si así se prevé en su normativa especifica sustancial o procedimental pudiendo en este caso pedir los 
Cónsules o el Personal Diplomático Nacional sito en el extranjero toda la información que necesiten a los servicios jurídicos de éstas destinados a dicho fin.

SÉPTIMA. El procedimiento comienza con la solicitud más los documentos que la justifican. El contenido de la solicitud debe asemejarse a la demanda y expresar el órgano al que se dirige, quien o quienes la solicitan, acto que se solicita y consecuencias o efectos jurídicos pedidos a su amparo, personas interesadas a las que se debe citar, justificaciones y probanzas que deben llevarse a cabo y en su caso actos de auxilio judicial o administrativo que se precisan.

Seguidamente se dictará providencia acordando citar a los interesados a una comparecencia, previniéndoles del lugar, día y hora en que se llevará a cabo; lugar y fecha para examinar la solicitud y documentos presentados; citación al Fiscal por fax o internet cuando es preceptiva su intervención para que informe y remita el dictamen escrito preceptivo sobre la legalidad de los actos solicitados; objeto, contenido y actos a practicar en la comparecencia para su eficacia.

En la fecha determinada se celebra la comparecencia oral informando el Cónsul o personal diplomático de su objeto, dará la palabra a los interesados que presentaron la solicitud, interesados que no iniciaron el expediente, peritos, testigos. Práctica de probanzas y en su caso del reconocimiento. Todo ello quedará grabado.

Resolución que adoptará la forma de Auto a dictar en el plazo de un mes contra la que no se admitirá recurso alguno sin perjuicio del derecho de los interesados a hacer contencioso el expediente y solicitar en la demanda del proceso que corresponda la suspensión de los efectos jurídicos de la resolución.

La resolución del Cónsul o personal diplomático si se la confiere carácter jurisdiccional, debería ser objeto de una homologación meramente formal y automática que se limite a constatar su adecuación o no a la legalidad material y formal de la norma aplicada por el Juez de Primera Instancia o Mercantil del lugar de España donde deba desplegar efectos y hacerse por auto sin necesidad de citar a los interesados y homologada por otro Auto se comunicará éste a todos los interesados a los efectos pertinentes. Contra éste no cabrá recurso alguno cualquiera que sea su contenido

Si a la resolución no se le quiere conferir carácter jurisdiccional si no sólo "administrativo», sería formalmente firme desde que se dicta por el Cónsul o personal diplomático sin caber recurso alguno 
y sin perjuicio del derecho de los interesados a acudir al proceso civil que corresponda. (Al tratarse de materias de derecho privado no es competente el orden jurisdiccional contencioso administrativo si no el civil).

OCTAVA. La redacción de los preceptos implicados de la futura Ley de Jurisdicción Voluntaria sería:

Artículo _. Los Cónsules Españoles y el Personal Diplomático de las Embajadas Españolas (el que se determine en las normas reguladoras de sus funciones y con la adecuada calificación jurídica) son competentes para conocer de los actos de jurisdicción voluntaria civil y mercantil que se deban adoptar o practicar en el extranjero donde España tenga Consulados o Embajadas y en los mismos casos que los Jueces de Primera Instancia. Quedan exceptuados los que siguen.... a determinar por civilistas o mercantilistas o por existir interés público que legitime al MF

En todo caso deberán respetar en la adopción y práctica de estos actos las competencias exclusivas del país extranjero en cuestión.

Artículo __. El procedimiento será único y el mismo para todos los actos que deban adoptarse o practicarse.

Será también el mismo que el seguido ante los Jueces de Primera Instancia y de lo Mercantil Españoles cuando se trate de actos de jurisdicción voluntaria civil o mercantil que formen parte de las competencias exclusivas del Estado. Las normas que actúan los Juzgados de lo civil y mercantil establecidas en esta Ley son de aplicación a los Cónsules y Personal Diplomático sin perjuicio de las especialidades que siguen.

Las Comunidades Autónomas podrán permitir en su normativa específica que los actos de jurisdicción voluntaria civiles, que sean de su exclusiva competencia, pertenecientes a su derecho histórico foral o que deriven de las competencias asumidas en su Estatuto de Autonomía referidas a su derecho autonómico pueden ser solicitados ante los Cónsules o Legaciones Españolas del país extranjero en que deban adoptarse o practicarse. En este caso los Cónsules o Legaciones Españolas en el extranjero podrán solicitar a los servicios jurídicos de la Comunidad Autónoma específica la información jurídica precisa de derecho sustancial o procedimental necesaria para ello.

Artículo _. . No produce efectos en ninguno de los supuestos previstos en esta Ley la abstención y recusación del Cónsul y personal diplomático. Tampoco podrán declararse incompetentes de oficio o 
a instancia de parte, sin perjuicio de su responsabilidad en caso de negativa a conocer de los expedientes de su competencia. Tampoco producen efectos las cuestiones prejudiciales que se planteen en estos expedientes de jurisdicción voluntaria.

Artículo

Si mientras se tramitan estos expedientes, algún interesado que no solicitó la actuación deseara convertir en contencioso el expediente podrá hacerlo sin más acudiendo a los órganos judiciales españoles competentes o a los órganos judiciales extranjeros del país en cuestión, sin que ello suponga alteración alguna sobre el procedimiento seguido ante los Cónsules o Personal Diplomático. Deberán ser las autoridades judiciales las que en su caso se pronuncien acordando la paralización, suspensión o sobreseimiento del procedimiento seguido ante aquéllos y/o de las medidas en su caso acordadas.

Artículo __. El trámite de audiencia al Ministerio Fiscal cuando sea preceptivo su dictamen -si las actuaciones se inician a instancia de interesados privados- se llevará a cabo directamente mediante fax o por internet escaneando la solicitud y documentos que la acompañan. De la misma forma se trasmitirá el informe escrito del Fiscal competente del lugar donde deban producirse en España dichos efectos que adoptará la forma escrita de dictamen. Este medio de comunicación seguirá el MF si recaba estas actuaciones de oficio siempre utilizando firma electrónica.

Artículo _. La resolución del Cónsul o personal diplomático adoptará la forma de Auto y será remitida por conducto diplomático al Ministerio de Asuntos Exteriores para que la haga llegar al de Justicia. Éste, a su vez, la hará llegar para su homologación al Juez de Primera Instancia o Juzgado Mercantil competente. Deberá ser homologada mediante otro Auto por el Juez de Primera Instancia o Mercantil del lugar donde deba producir efectos. Se limitará en la homologación a comprobar que se respetó por el Cónsul y el personal diplomático la legalidad sustancial y procedimental ratificándola o modificándola.

La homologación se hará de forma automática y directa e igualmente por resolución que adoptará la forma de Auto, y en un procedimiento informal de jurisdicción voluntaria en el que no se dará audiencia a los interesados. Será homologada, sin más, siempre que se ajuste en su contenido al ordenamiento jurídico español. En otro caso, la homologación tendrá por objeto adecuar la resolución del Cónsul o del personal diplomático a éste. 
En ambos casos, el auto de homologación se comunicará a los interesados y contra éste no cabe recurso alguno sin perjuicio del derecho de los interesados a hacer contencioso el expediente ante el Juez competente de dicho proceso.

Los Jueces de Primera Instancia o de lo Mercantil que la homologuen se encargarán, en todo caso, de velar por el cumplimiento de la resolución adoptando si fuera preciso mandatos de ejecución indirecta y determinando el tiempo y forma del cumplimiento.

Artículo . Precepto alternativo al anterior para el supuesto (¿más o menos probable?) que no se desee que tenga carácter jurisdiccional la decisión del Cónsul o personal Diplomático si no meramente administrativa.

La resolución de los Cónsules y Personal Diplomático una vez dictada es definitiva y firme no cabiendo recurso alguno contra la misma. Ello sin perjuicio del derecho de los interesados a hacer contencioso el expediente y de solicitar en la demanda del proceso civil correspondiente y ante el Órgano judicial competente que corresponda (nacional o extranjero) la suspensión de los efectos de la misma.

Artículo _. En los asuntos seguidos ante los Cónsules y Personal Diplomático será facultativa en todo caso la intervención de abogado y procurador.

Los gastos de las actuaciones referidas a indemnización de testigos, honorarios de peritos y reclamación de documentos en archivos públicos o privados correrán a cargo de quien las solicite y si son varios serán proporcionales a la parte solicitada por cada una, atendiendo a la cuantía.

Los gastos que conlleven las actuaciones de los Cónsules y el Personal Diplomático serán gratuitas y a cargo de los presupuestos del Ministerio de Asuntos Exteriores.

\section{BIBLIOGRAFÍA}

ALCALÁ ZAMORA Y CASTILLO, N.: La eficacia de las providencias de jurisdicción voluntaria. VVAA. Atti dei III Congreso internazionale di diritto processuale civile. Milano.1969. Pág. 533 y ss. 
- Premisas para determinar la índole de la llamada jurisdicción voluntaria. R.,D.,Pr.,Argentina. 1949-1 y 2, pág. 287 y ss. Idem. en Studi in onore de Enrico Redenti. Milano. 1951. Pág. 5 y ss.

ALLORIO, E.: Nuovi Riflessioni in tema de giurisdizione e di giudicato. Riv. Trim. Dir. Proc. Civ. 1957. Pág. 90 y ss. Idem en Scriti in memoriam de Pietro Calamandrei. T. II. Padova. 1858.

- Saggio polemico sulla giurisdizione volontoria. Riv. Trim. Dir. Proc. Civ. 1948, pág. 45 y ss. Idem en Problemas de Derecho Procesal T. II. Buenos Aires. 1963.

ALMAGRO NOSETE, J.: El libre acceso como derecho a la jurisdicción. Revista de la Facultad de Derecho de la Universidad de Madrid. Tomo XIV. N. ${ }^{\circ}$ 37. 1970.

ALMAGRO NOSETE, J. (con TOMÉ PAULÉ, J).: Instituciones de Derecho Procesal Civil . Tomo II. Pág. 505 y ss. Madrid 1992.

ALONSO FURELOS, J.M.: Competencia de las Comunidades Autónomas para legislar en materia procesal. Revista electrónica de la Facultad de Derecho de la UNED. Número 1. Monográfico de la Constitución Española.

- La Competencia exclusiva del Estado para legislar en materia procesal prevista en el artículo $149-1-5 .^{\circ}$ y $6 .^{\circ}$ de la Constitución Española y sus excepciones. San Sebastián. 2007.

- Constitución y Jurisdicción Voluntaria. En Constitución y democracia ayer y hoy. Libro homenaje a Antonio Torres del Moral. Vol. II. Pág. 1577 y ss. Madrid 2013.

- Reflexiones sobre la vigente legislación española de la jurisdicción voluntaria en su parte general y bases para su reforma. Madrid. 2012.

ÁLVAREZ CASTELLANOS RAEL, P.: El proceso de jurisdicción voluntaria. R. D. Pr. 1945-3, pág. 331 y ss.

ANDRIOLI, V.: Il processo civile non contencioso. Anuario di diritto comparato. 1966

AUGER, C.: Reforma de la Jurisdicción voluntaria. AAM Notariado. 1992-3

BARATTA: La natura giuridica degli atti di volontoria giurisdizione. R.D.Not.1965 pág 778 y ss.

BELLOCH JULVE, J.A.: Notas en torno al Notario y a la jurisdicción voluntaria. R. J. Cat. 1992-2. Pág. 9 y ss. 
BENECKE W.: Tratado de los principios del resarcimiento en los seguros marítimos y en las obligaciones a la gruesa. Notas y apéndice al derecho español de Torrents. Barcelona. 1841.

BLASI DI. Giurisdizione Volontoria. Nuevo Digesto Italiano. T. 7. 1957.

BRAUNA, R.: Dizionario della volontoria giurisdizione. Milano. 1999.

CALAMANDREI, P.: Limite tra giurisdizione e amministrazione. Studi sul processo civile. Vol. I. Padova. 1930.

CARNELUTTI, F.: Instituzioni del nuovo processo civile italiano. Roma. 1951.

CARRERAS, J.: Eficacia de las resoluciones de jurisdicción voluntaria RIbD Proc. 1962. Idem. Estudios de Derecho Procesal (con Fenech M.) Barcelona.1982.

CASTÁN TOBEÑAS, J.: Función notarial. Elaboración notarial del Derecho. Madrid. 1964.

Código de Comercio de 1829. Edición Oficial, Madrid. 1829.

Código de Comercio de 1885. Edición Oficial. Madrid. 1885.

CHIOVENDA, J.: Instituciones de Derecho Procesal Civil. Traduce GÓMEZ ORBANEJA, E.: T. III. Madrid. 1940.

- Principios de Derecho Procesal Civil. Traduce Casais Santaló, J. Madrid. 2 T. 1922. 1925.

CHIZZINI, A.: La revoca dei provvedimenti di volontoria giurisdizione. Padova. 1991.

CRISTOFALINI, C.: Efficacia dei provvedimenti di giurisdizione volontoria. Studi in onore de Chiovenda. Padova. 1927, pág. 377 y ss.

CULOT, D.: La volontoria giurisdizione e lo stranjero. Milano. 1995.

DE LA OLIVA, A. y DÍEZ PICAZO, I.: Derecho Procesal Civil. 2 T. Madrid. 2000.

DENTI. La giusidizione volontoria rivisata. Studi in Onore de E. Allorio. Milano. 1989

FAIRÉN GUILLÉN, V.: El auxilio de los Tribunales y la jurisdicción voluntaria. Justicia. 1992-4. Pág. 789 y ss.

- Jurisdicción voluntaria. Juicios Sumarios. Las confusiones en la historia y su evolución. Posibles soluciones. BCAM. 1990-2 
- Sobre el paso de la jurisdicción voluntaria a la contenciosa. El artículo 1817 de la Ley de Enjuiciamiento Civil y la problemática actual. ADC. 1991, pág. 309 y ss.

FAZZALARI, E.: I procedimentti in camera di consiglio e la tutela de diritti. Milano. 1981.

— La giurisdizione volontoria. Padova. 1953.

FERNÁNDEZ BUJÁN, A.: Hacia una teoría general de la jurisdicción voluntaria. La jurisdicción voluntaria en las Cortes Generales. 2 Vol. Madrid 2007-2008.

- Jurisdicción voluntaria, naturaleza jurídica y diferencias de procedimiento con la jurisdicción contenciosa. AC. 2001. N. ${ }^{\circ}$ 36-37.

— La jurisdicción voluntaria. Madrid. 2001.

— La jurisdicción voluntaria en el Derecho Romano. Madrid. 1986.

- La reforma de la jurisdicción voluntaria: problemas, interrogantes, soluciones. La Ley 23-3-1905

- Reflexiones y propuestas a propósito de la futura Ley de la Jurisdicción Voluntaria. R. J. Notariado N. ${ }^{\circ}$ 79. 2012. Pág. 177 y ss; Idem. en RD UNED. N..$^{\circ} 11.2012$. Pág. 961 y ss.

- Para una selección de su amplia bibliografía sobre jurisdicción voluntaria puede verse la hecha por él en la cita 2 de la obra antes citada y la realizada por su discípula Calaza López, S. en la cita 3 del homenaje a este profesor en su XXV aniversario de catedrático que aparece en la RDUNED N. 32008 , pág. 347 y ss.

GIMENO GAMARRA, A.: Ensayo de una teoría sobre la jurisdicción voluntaria. ADC. 1953. Pág. 3 y ss.

GÓMEZ COLOMER con MONTERO AROCA y MONTÓN REDONDO: Derecho Jurisdiccional. T. 2. ${ }^{\circ}$ Barcelona. 1993.

GÓMEZ DE LA SERNA, P.: con REUS GARCÍA, J.: Código de Comercio... 5. ${ }^{\text {a }}$ edic. Madrid. 1869.

GÓMEZ ORBANEJA, E.: con Herce Quemada, V. Derecho Procesal Civil. T. II. Madrid. 1980.

GONZÁLEZ POVEDA. La jurisdicción voluntaria. Doctrina y formu-

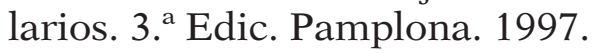

GRIGNANI, G.: Volontaria Giurisdizione: schemi di diritto procesuale civile. Padova. 1989. 
GUASP DELGADO, J.: Derecho Procesal Civil. Tomo 2. ${ }^{\circ}$ Madrid. 1968. JANNUZZI, A.: Manualle della volontoria giurisdizione. Milano 2000. LASO GAITE, F. Crónica de la Codificación Española. Codificación Mercantil. Vol. 6. ${ }^{\circ}$ Ministerio Justicia. Madrid. 1999.

- Crónica de la Codificación Española. Organización Judicial. Vol. 1. ${ }^{\circ}$ Ministerio Justicia. Madrid. 1998-99

- Crónica de la Codificación Española. Procedimiento Civil. Vol. 2. Ministerio Justicia. Madrid. 1998-99.

Ley de Enjuiciamiento Civil de 1881. Edición Oficial. Madrid. 1881.

Ley de Enjuiciamiento sobre los Negocios y Causas de Comercio 1830. Edición Oficial. Madrid. 1830

LIEBMAN, E. T.: Giurisdizione voluntaria e competenza. R.T.D.P.C. 1925.

- Impugnazione in sede contenciosa del provvedimento di giurisdizione volontoria. RDDPC. 1953-2

Llibre del Consolat del Mar. Tractant del Fets Maritims. Traduce PARELLADA, J. R.: MAExteriores. 2 Vol. 1955. Valencia.

MANRESA NAVARRO, J. M.: Comentarios a la LEC reformada.... 6 Vol. Madrid. 1888-95.

MARINI, De.: Considerazione sulla natura della giurisdizione volontoria RDPr. 1954. Pág. 254 y ss.

MAS Y CLOTET, J.: Manual se seguros marítimos. Nuevo sistema... Madrid. 1861.

MICHELI, J. A.: Corso di diritto processuale civile. 4 Vol. Milano. 1955.

MIGUEL ASENJO, P. A.: Eficacia de las resoluciones extranjeras de jurisdicción voluntaria. Madrid. 1997.

MILANS DEL BOSCH PÓRTOLES, I.: La determinación del derecho aplicable en los actos de jurisdicción voluntaria. REDI. 1987, pág. 67 y ss.

MUÑOZ ROJAS, T.: Jurisdicción voluntaria en el ámbito hipotecario. AC. 1994. Pág. 19 y ss.

— Sobre la jurisdicción voluntaria. AC 1989-9 y 1990-39. Pág. 409 y ss. 
NERI, B.: Volontoria giurisdizione: profili processuale. Torino. 1999.

Ordenanzas (de la muy Ilustre casa de contratación y del consulado...) de Bilbao. Los Códigos Españoles. Vol. XII. Madrid. 1851.

PEÑA BERNARDO DE QUIRÓS, C. M.: Formularios y práctica jurídica comentada de jurisdicción voluntaria. Granada. 2000.

PODETTI, J. R.: La giurisdizione volontoria. Padova. 1986.

PRADA GONZÁLEZ: En torno a la futura Ley de Jurisdicción Voluntaria. El Notariado del siglo XXI. Diciembre 2005.

- Por qué ha fracasado el proyecto de Ley de Jurisdicción Voluntaria. El Notariado del siglo XXI. N. ${ }^{\circ}$ 16, 2007

PRIETO CASTRO Y FERRANDIZ, L.: Deberes ineludibles e inaplazables. (El laberinto de la quiebra y de la jurisdicción voluntaria y el formalismo de la casación). Temas de derecho actual y su práctica. Salamanca. 1979, pág. 249 y ss.

- Reflexiones doctrinales y legales sobre la jurisdicción voluntaria. RDPriv. 1956. Pág. 120 y ss.

RAMOS MÉNDEZ, F.: ¿Cuanta dosis de jurisdicción voluntaria necesitamos? Justicia. 2006.

— Derecho Procesal Civil. Vol. 2. ${ }^{\circ}$ Barcelona. 1990.

- La jurisdicción voluntaria en negocios de comercio. Madrid. 1978.

RODRÍGUEZ ADRADOS, A.: El Anteproyecto de Ley de Jurisdicción Voluntaria. Anales de la RAJLJ. Madrid. 2006.

RUIZ GUTIÉRREZ, U.: La competencia territorial en relación a los actos de jurisdicción voluntaria. RDProc. 1966-3. Pág. 97 y ss.

SATTA, S.: Diritto Processuale Civile. Padova. 1953.

SEOANE CACHARRÓN, J.: Breve examen crítico del Anteproyecto de Ley de Jurisdicción Voluntaria del Ministerio de Justicia de 1-6-2006. La Ley 26 septiembre 2006.

- El Secretario Judicial como órgano de la jurisdicción voluntaria en el Proyecto de Ley de 27 de octubre de 2006. La Ley de 15 de mayo de 2007.

- Examen del procedimiento judicial común en el Proyecto de Ley de Jurisdicción Voluntaria. La Ley de 6 de septiembre de 2007 
SERRA DOMÍNGUEZ, M.: Jurisdicción Voluntaria. (Voz) Nueva Enciclopedia Jurídica Seix. 1968. Tomo XIV, pág. 583 y ss. Idem. Naturaleza de la jurisdicción voluntaria. Estudios de Derecho Procesal Barcelona. 1969.

URRUTIA SALAS, M.: La jurisdicción voluntaria. RD. Pr. Arg. 1951-3 y 4, pág. 303 y ss.

VICENTE Y CARAVANTES, J. de: Código de Comercio extractado y comentado... 4. ${ }^{\text {a }}$ edic. Madrid. 1848.

- Tratado elemental de los procedimientos sobre negocios y causas de comercio con arreglo... Madrid. 1850.

VV.AA. Atti del XVII Convengo Nazionale del Processo Civile. Palermo. 1989.

ZANOBINI, E.: Sull' amministrazione publica del diritto privato. R.D. Publ. 1918. Pág. 183 y ss. 